
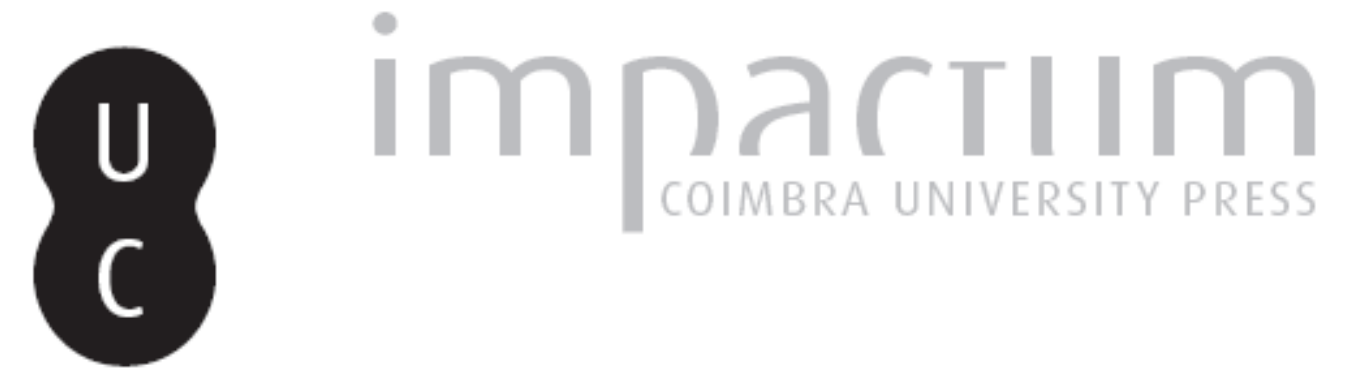

A posição dos partidos políticos portugueses face à guerra da Bósnia-Herzegovina (1992-1995)

\author{
Autor(es): $\quad$ Almeida, Ana Luísa da Rocha \\ Publicado por: Imprensa da Universidade de Coimbra \\ URL \\ persistente: \\ URI:http://hdl.handle.net/10316.2/35441 \\ DOI: \\ DOI:http://dx.doi.org/10.14195/0870-4147_45_22 \\ Accessed : $\quad$ 26-Apr-2023 13:52:31
}

A navegação consulta e descarregamento dos títulos inseridos nas Bibliotecas Digitais UC Digitalis, UC Pombalina e UC Impactum, pressupõem a aceitação plena e sem reservas dos Termos e Condições de Uso destas Bibliotecas Digitais, disponíveis em https://digitalis.uc.pt/pt-pt/termos.

Conforme exposto nos referidos Termos e Condições de Uso, o descarregamento de títulos de acesso restrito requer uma licença válida de autorização devendo o utilizador aceder ao(s) documento(s) a partir de um endereço de IP da instituição detentora da supramencionada licença.

Ao utilizador é apenas permitido o descarregamento para uso pessoal, pelo que o emprego do(s) título(s) descarregado(s) para outro fim, designadamente comercial, carece de autorização do respetivo autor ou editor da obra.

Na medida em que todas as obras da UC Digitalis se encontram protegidas pelo Código do Direito de Autor e Direitos Conexos e demais legislação aplicável, toda a cópia, parcial ou total, deste documento, nos casos em que é legalmente admitida, deverá conter ou fazer-se acompanhar por este aviso.

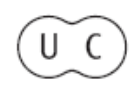




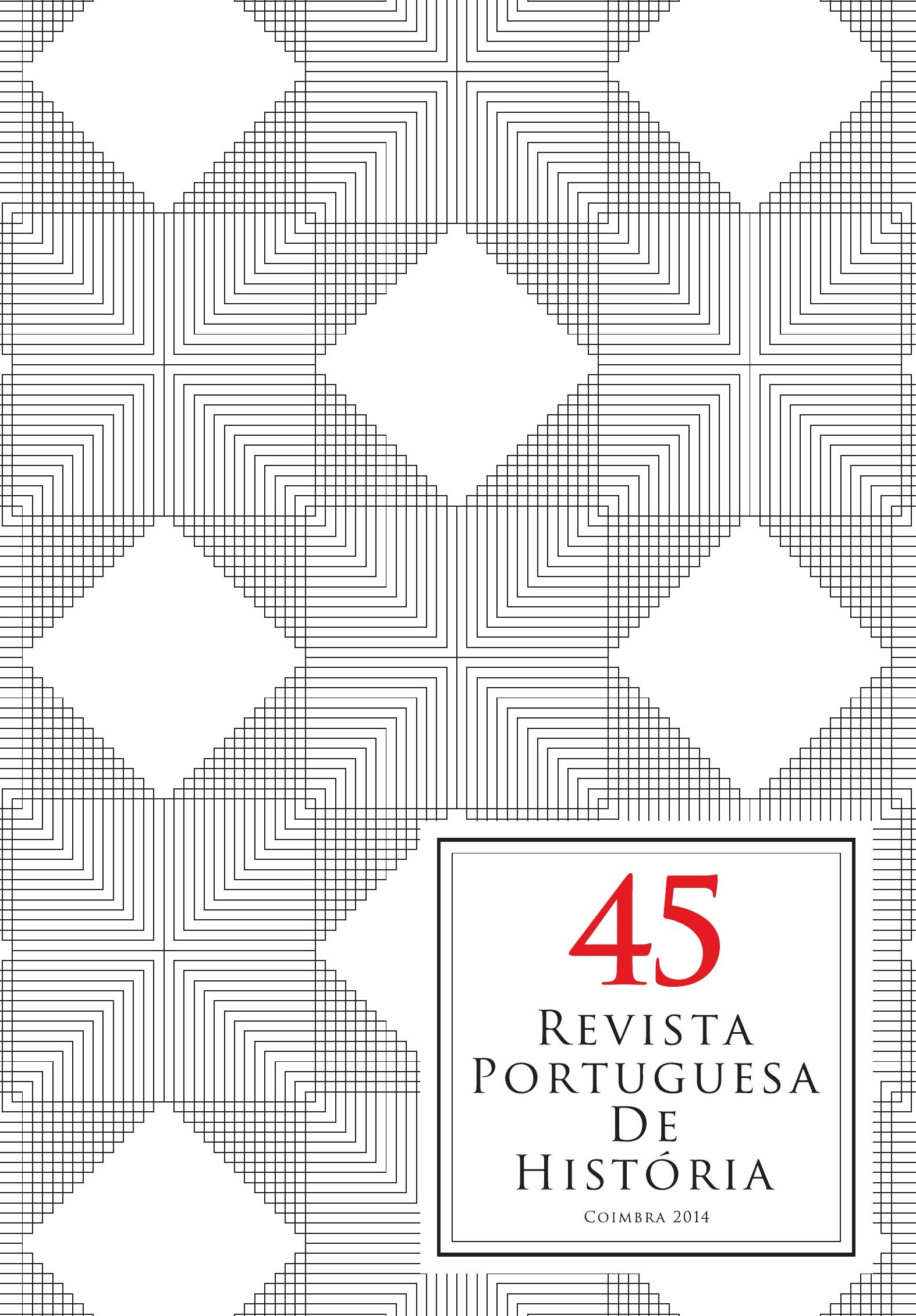




\title{
A posição dos partidos políticos portugueses face à guerra da Bósnia-Herzegovina (1992-1995)
}

\author{
The position of the Portuguese political parties concerning \\ the Bosnian war (1992-1995)
}

\author{
Ana Luísa da Rocha Almeida \\ Universidade do Porto \\ alrochaalmeida@gmail.com
}

\section{Resumo:}

O presente artigo foca-se na posição dos partidos políticos portugueses com representação parlamentar, aquando da explosão da guerra na ex-Jugoslávia. Para tal, foram estudadas as intervenções em plenário da Assembleia da República entre 1993 e 1995, que têm como denominador comum o debate do conflito na Bósnia-Herzegovina. A imprensa partidária foi, igualmente, alvo de investigação, no intuito de compreender até que ponto esta guerra foi referida e/ou explorada nas publicações dos partidos políticos com assento parlamentar em Portugal.

As questões que fundamentalmente guiaram esta investigação foram: De que modo os partidos políticos portugueses demonstraram inquietação para com a situação na ex-Jugoslávia? Qual a posição dos partidos políticos com representação no Parlamento relativamente à ex-Jugoslávia e ao conflito na Bósnia-Herzegovina e de que forma tal preocupação era visível nas suas publicações? De que forma o Parlamento encarou a posição do Governo face à guerra nos Balcãs?

Em suma, trata-se de um trabalho que tem como principal objetivo caracterizar a posição dos partidos políticos com representação parlamentar bem como da imprensa partidária, tendo como cenário o conflito na Bósnia-Herzegovina (1992-1995).

\section{Palavras chave:}

Guerra; (ex)Jugoslávia; Bósnia-Herzegovina; Portugal; intervenções parlamentares; imprensa partidária.

\section{Abstract:}

This article focuses on the position of Portuguese political parties with parliamentary representation, at the outbreak of war in former Yugoslavia. To this end, all plenary interventions were studied between 1993 and 1995, with a common denominator: the discussion of the conflict in Bosnia-Herzegovina. The partisan press was also subject to investigation in order to understand the extent to which this war was reported and operated in the publications of the political parties in Parliament in Portugal.

The issues that ultimately guided this research were: How do political parties have shown concern for the situation in former Yugoslavia? What was the position of the political parties with parliamentary representation in Portugal regarding former Yugoslavia and the conflict in Bosnia-Herzegovina and how was this concern evident in their publications? In what way did parliament face the government's position against the war in the Balkans?

In short, this is a work that has as its main objective to characterize the position of the political parties in Parliament and its partisan press, against the backdrop of the conflict in Bosnia-Herzegovina (1992-1995).

\section{Keywords:}

War; (former) Yugoslavia; Bosnia-Herzegovina; Portugal; parliamentary speeches; partisan press. 


\section{Introdução}

O presente artigo foi redigido a partir da Dissertação realizada no âmbito do Mestrado em História, Relações Internacionais e Cooperação da Faculdade de Letras da Universidade do Porto, com início em 2010 e término em 2012, tendo como orientador o Professor Doutor Manuel Loff, do Departamento de História e Estudos Políticos e Internacionais.

A motivação que me conduziu à seleção e investigação deste tema data da adolescência, sensivelmente aos treze anos de idade, pelo intermédio de uma professora de Geografia da escola que então frequentava. No âmbito dessa disciplina foi-me pedido que organizasse um kit de higiene juntamente com os restantes colegas da turma, para ser enviado para o Kosovo, tendo como principais destinatários crianças e mulheres, vítimas dos bombardeamentos. A guerra ia sendo diariamente transmitida pelos media e o interesse por tal região fora naturalmente desenvolvendo, tendo para tal reunido artigos, com o objetivo de criar um dossier única e exclusivamente sobre o conflito e a ex-Jugoslávia, bem como outro tipo de informações que me permitissem compreender a razão pela qual sentia tal curiosidade e simpatia pela região. Seria, contudo, no último ano de Licenciatura (2007/2008) que teria a oportunidade de, pela primeira vez, utilizar as fontes que havia agrupado sobre o tema, no âmbito da disciplina de Política Internacional, lecionada pelo Professor Doutor Manuel Loff.

Naturalmente que ao optar pelo Mestrado em História, Relações Internacionais e Cooperação já tinha refletido sobre a possibilidade de aprofundar a investigação relativamente à ex-Jugoslávia, procurando compreender e analisar a guerra da Bósnia-Herzegovina, dada a inexistência de bibliografia e estudos em língua portuguesa sobre o tema.

O projeto de Dissertação, numa primeira fase, pretendia abordar a política externa portuguesa ou as relações entre a República Portuguesa e a República da Bósnia-Herzegovina, tendo como contextualização histórica a guerra na ex-Jugoslávia. Para tal, foi importante a elaboração de trabalhos que me permitissem explorar diferentes áreas de estudo, desde a geografia à política, bem como a cultura (até mesmo o desporto) e a religião, no intuito de conseguir optar pela mais adequada e, sobretudo, original.

Numa segunda fase, o tema parecia estar escolhido: a análise da posição dos partidos políticos com representação parlamentar em Portugal face à guerra da Bósnia-Herzegovina no período compreendido entre 1992 e 1995. Esta investigação pretende, deste modo, preencher uma lacuna que subsiste, com particular evidência, no campo das Relações Internacionais em Portugal, 
no que respeita ao(s) conflito(s) nos Balcãs. Ainda que esse assunto seja, nos dias de hoje, alvo de contínuos estudos, especialmente no âmbito dos Estudos Militares ou da Geoestratégia, a guerra da Bósnia-Herzegovina pouco havia sido analisada do ponto de vista político, tendo como pano de fundo a política externa portuguesa na década de 90 . Tornou-se, portanto, evidente qual a abordagem a adotar.

As questões que fundamentalmente guiaram esta investigação foram: De que modo os partidos políticos portugueses demonstraram inquietação para com a situação na ex-Jugoslávia? Qual a posição dos partidos políticos com representação no Parlamento relativamente à ex-Jugoslávia e ao conflito na Bósnia-Herzegovina e de que forma tal preocupação era visível nas suas publicações? De que forma o Parlamento encarou a posição do Governo face à guerra nos Balcãs?

Tendo em mente as questões acima colocadas, tornou-se claro o objetivo desta investigação subjacente: analisar o debate político em torno do conflito da Bósnia-Herzegovina, através das intervenções parlamentares e da imprensa partidária.

Por motivos de natureza pessoal e profissional não foi possível a realização de entrevistas a parlamentares, recorrendo, assim, à investigação da literatura existente. Foram privilegiadas as intervenções de parlamentares entre 1993 e 1995 relativamente à guerra da Bósnia-Herzegovina ou à ex-Jugoslávia, disponíveis no sítio de Internet do Parlamento.

Ainda assim, e de modo a aceder à documentação oficial diplomática, foi contactada, por duas vezes, a Missão Temporária de Portugal em Sarajevo, mais precisamente o chefe da Missão António Maria Vieira Botelho de Sousa ${ }^{1}$, mas sem sucesso.

Como parte constituinte da investigação, a imprensa partidária foi analisada. Procedeu-se ao levantamento de todos os artigos no período 1992-1995 das publicações periódicas do Partido Socialista, Partido Social Democrata e Partido Comunista Português respetivamente: Acção Socialista, Povo Livre e Avante!, disponíveis na Biblioteca Pública Municipal do Porto. Contudo, referencio o facto da inexistência de uma publicação do Partido do Centro Democrático Social - Partido Popular.

\footnotetext{
${ }^{1}$ Foi enviada uma mensagem em dois momentos, no intuito de conseguir obter informações passíveis de serem utilizadas. Tal mensagem foi enviada nos dias 02/05/2011, dirigida a Sónia Melo e Castro, encarregada de negócios da Embaixada de Portugal em Sarajevo, e a 08/04/2011, dirigida a António de Sousa (chefe da missão). Na altura, o tema da tese concentrava-se nas relações diplomáticas entre Portugal e a Bósnia-Herzegovina, aquando do conflito 1992-1995.
} 
no que respeita ao(s) conflito(s) nos Balcãs. Ainda que esse assunto seja, nos dias de hoje, alvo de contínuos estudos, especialmente no âmbito dos Estudos Militares ou da Geoestratégia, a guerra da Bósnia-Herzegovina pouco havia sido analisada do ponto de vista político, tendo como pano de fundo a política externa portuguesa na década de 90 . Tornou-se, portanto, evidente qual a abordagem a adotar.

As questões que fundamentalmente guiaram esta investigação foram: De que modo os partidos políticos portugueses demonstraram inquietação para com a situação na ex-Jugoslávia? Qual a posição dos partidos políticos com representação no Parlamento relativamente à ex-Jugoslávia e ao conflito na Bósnia-Herzegovina e de que forma tal preocupação era visível nas suas publicações? De que forma o Parlamento encarou a posição do Governo face à guerra nos Balcãs?

Tendo em mente as questões acima colocadas, tornou-se claro o objetivo desta investigação subjacente: analisar o debate político em torno do conflito da Bósnia-Herzegovina, através das intervenções parlamentares e da imprensa partidária.

Por motivos de natureza pessoal e profissional não foi possível a realização de entrevistas a parlamentares, recorrendo, assim, à investigação da literatura existente. Foram privilegiadas as intervenções de parlamentares entre 1993 e 1995 relativamente à guerra da Bósnia-Herzegovina ou à ex-Jugoslávia, disponíveis no sítio de Internet do Parlamento.

Ainda assim, e de modo a aceder à documentação oficial diplomática, foi contactada, por duas vezes, a Missão Temporária de Portugal em Sarajevo, mais precisamente o chefe da Missão António Maria Vieira Botelho de Sousa ${ }^{1}$, mas sem sucesso.

Como parte constituinte da investigação, a imprensa partidária foi analisada. Procedeu-se ao levantamento de todos os artigos no período 1992-1995 das publicações periódicas do Partido Socialista, Partido Social Democrata e Partido Comunista Português respetivamente: Acção Socialista, Povo Livre e Avante!, disponíveis na Biblioteca Pública Municipal do Porto. Contudo, referencio o facto da inexistência de uma publicação do Partido do Centro Democrático Social - Partido Popular.

\footnotetext{
${ }^{1}$ Foi enviada uma mensagem em dois momentos, no intuito de conseguir obter informações passíveis de serem utilizadas. Tal mensagem foi enviada nos dias 02/05/2011, dirigida a Sónia Melo e Castro, encarregada de negócios da Embaixada de Portugal em Sarajevo, e a 08/04/2011, dirigida a António de Sousa (chefe da missão). Na altura, o tema da tese concentrava-se nas relações diplomáticas entre Portugal e a Bósnia-Herzegovina, aquando do conflito 1992-1995.
} 
Foram ainda privilegiados os congressos e programas eleitorais ${ }^{2}$ no período em análise. De facto, foi importante aceder à documentação resultante dos congressos dos partidos políticos com representação parlamentar, bem como as resoluções, declarações/comentários e notas de imprensa, no intuito de perceber até que ponto o contexto internacional e, eventualmente, a política externa portuguesa desempenhava um papel importante no seio do debate político. Foram contactados os partidos políticos em análise, solicitando o acesso aos programas dos congressos, realizados entre 1992 e $1995 .{ }^{3}$ Os websites dos partidos selecionados foram altamente valorizados. Destacam-se, ainda, as páginas de algumas organizações internacionais, cadeias televisivas e centros de documentação/ investigação, tendo sido recorrente a sua consulta ao longo de 2010 e 2011.

Foram ainda utilizados relatórios, conclusões e correspondência diplomática registados na Comissão Parlamentar dos Assuntos Europeus e dos Negócios Estrangeiros, Comunidades Portuguesas e Cooperação durante o período em estudo. O acesso a esta documentação foi possível através da análise e levantamento no Arquivo Histórico Parlamentar, consultado em Lisboa, em fevereiro de 2012.

As obras, bem como os artigos, de natureza político-diplomática, tanto nacionais, como internacionais foram, igualmente, privilegiados. Destaca-se, a este título, a obra de José Cutileiro intitulada Vida e Morte dos Outros: A Comunidade Internacional e o fim da Jugoslávia (2003), que consegue providenciar uma visão do conflito um tanto intimista e, sobretudo, realista. Convém referir que José Cutileiro, que havia chefiado a delegação de Portugal na África do Sul até janeiro de 1992, foi uma das personalidades que sobressaiu no contexto internacional, durante o processo de negociações, com vista a uma solução política nos Balcãs. Permaneceu, pois, uma fonte regularmente utilizada ao longo de toda a investigação. Foi, ainda, estabelecido contacto com este embaixador, através do Consulado da República da Sérvia em Portugal, que mostrou disponibilidade para apreciar a investigação, tendo considerado que a mesma "está bem escrita (obrigação que nem todos os investigadores

${ }^{2}$ A este título foram contactados os quatro partidos políticos de modo a obter informações relativas às resoluções dos congressos realizados entre 1990 e 1995. Na ausência dos mesmos, foram considerados os programas eleitorais desse período.

${ }^{3}$ Foi apenas possível aceder às resoluções dos programas do XVI Congresso do PSD (13 a 15/11/1992); do X Congresso do CDS-PP (20/03/1992); do XIII Congresso do CDS-PP (11/02/1995) e ao do XIV Congresso do PCP (4, 5 e 6/12/1992). 
respeitam), consegue em poucas páginas enquadrar previamente o inquérito a que procede; inquérito bem pensado e bem apresentado."4

Evidencia-se, da mesma forma, a obra do jornalista e investigador Carlos Santos Pereira, Da Jugoslávia à Jugoslávia, os Balcãs e a Nova Ordem Europeia (1999), tendo contribuído claramente para um melhor entendimento quer da região da ex-Jugoslávia, nas suas várias vertentes, quer da Bósnia-Herzegovina em particular.

Relativamente ao conflito propriamente dito, foi frequente o uso da obra intitulada Ethnic Conflict and International Intervention: Crisis in Bosnia-Herzegovina, 1990-93 (2000) de Steven L. Burg e Paul S. Shoup, que constituiu uma fonte fundamental para compreender a guerra na Bósnia-Herzegovina. É, sem dúvida, uma obra que oferece uma visão acessível mas detalhada da problemática, recorrendo, para tal, a inúmeras fontes da região, da imprensa internacional bem como a entrevistas. Também a obra com o título The Yugoslav Wars: No. 2: Bosnia, Kosovo and Macedonia 1992-2001 (2006) de Nigel Thomas foi importante, já que apresenta uma descrição dos exércitos, da guerra de independência da Croácia (1991-1992) e da guerra da Bósnia-Herzegovina (1992-1995).

No que diz respeito à história da ex-Jugoslávia e/ou Bósnia-Herzegovina, foram utilizadas três obras como referência: Yugoslavia as History: Twice There Was a Country (2000) de John R. Lampe, que analisa o background histórico da Jugoslávia e os conflitos que dissolveram a federação; a obra de Leslie Benson intitulada Yugoslavia: a concise History (2004), que examina o curso da história do país de uma forma geral e a obra The History of Bosnia: From the Middle Ages to the Present Day (2007) de Marko Attila Hoare, que assenta num estudo sobre a identidade nacional e as origens da Bósnia-Herzegovina, tendo em consideração os períodos otomano, austro-húngaro e jugoslavo.

Além deste tipo de fontes, as produções cinematográficas revelaram-se instrumentos pertinentes, tendo optado por recorrer, sempre que necessário, aos mesmos, pelo facto de providenciarem testemunhos, teorias e informações, de uma forma bastante original, informal e, por vezes, sarcástica. Foi justamente a partir de alguns filmes, destacando a título exemplificativo os de autoria de Emir Kusturica, desde Underground (1995) ou Zivot je cudo (2004), bem como documentários de realizadores, na sua maioria, sérvios e/ou bósnios, que foi possível aceder a mais informação sobre o tema. Salienta-se, também, a produção da BBC The Death of Yugoslavia (1995), Yugoslavia: The Avoidable

\footnotetext{
${ }^{4}$ E-mail de José Cutileiro à [autora], 08/06/2012
} 
War (1999) de George Bogdanich ou ainda Once Brothers (2010) de Michael Tolajian. O objetivo era conseguir aceder a ficções, a documentários e a vídeos que, de algum modo, desenvolvessem a relação humana e drama social.

Foram, ainda, realizadas duas deslocações aos Balcãs, mais precisamente, à Sérvia, à Bósnia-Herzegovina, à Croácia, ao Montenegro, à Macedónia e ao Kosovo em em outubro de 2010 e junho de 2011. Com estas viagens, foi possível o contacto in loco com a região, tendo organizado o itinerário em função do decurso e objetivos da investigação. Para tal, foi útil a visita a vários museus, com destaque para o Museu da História da Jugoslávia, situado em Belgrado (Sérvia), bem como ao túmulo de Josip Broz Tito. Também, na Bósnia-Herzegovina, mais precisamente em Sarajevo, foi visitado o museu de Alija Izetbegović e o Tunnel Museum, e em Mostar, várias exposições fotográficas relacionadas com a cidade, com o antes, o durante e o após o conflito.

Durante este trajeto, foi possível obter relatos da população sobre o conflito, bem como contactar com a sua visão relativamente ao passado e os seus receios futuros, que se refletem no capítulo das conclusões. Parte destes relatos foram gravados, bem como a redação de algumas notas pessoais que poderiam ser, eventualmente, proveitosas no âmbito da investigação a outro nível. No entanto, tais testemunhos, não foram considerados. Algum material fotográfico foi ainda reunido e utilizado no decorrer da investigação.

Relativamente à estrutura, este artigo versa-se sobre o debate político face à guerra da Bósnia-Herzegovina e ex-Jugoslávia, constituindo, deste modo, $\mathrm{o}$ centro quer da Dissertação, quer da investigação. Neste sentido, foi necessário proceder ao levantamento de diversas fontes, nomeadamente as intervenções parlamentares em plenário, a imprensa partidária, os programas eleitorais e dos congressos, a documentação diplomática, bem como outros documentos de instituições europeias e internacionais. Para complementar a análise foram também consultados artigos de imprensa publicados no Jornal de Notícias e no Diário de Notícias.

Apesar de no presente artigo não ser desenvolvido em pormenor o tema das guerras de independência; o conflito da Bósnia-Herzegovina (1992-1995) e o envolvimento diplomático de Portugal na ex-Jugoslávia, tal havia sido feito aquando da redação da Dissertação.

\section{A política portuguesa e o conflito na Bósnia-Herzegovina}

Segundo José Cutileiro e João Mira Gomes, ambos embaixadores para a paz na ex-Jugoslávia, os partidos políticos portugueses apenas se manifestaram diretamente sobre o conflito e a região aquando da Presidência Portuguesa das 
Comunidades Europeias no primeiro semestre de 1992, que terá constituído um desafio que haveria de ser determinante para a afirmação de um estado periférico com uma atitude pouco intervencionista, na cena internacional.

Face a estas opiniões, levantam-se as seguintes questões: Qual terá sido a posição dos partidos políticos portugueses com assento parlamentar face à eclosão de uma guerra em plena remodelação do projeto europeu? Como terá decorrido o debate político (parlamentar e internamente nos partidos) relativamente ao desenrolar do conflito? Quem terão sido as figuras mais ativas neste período?

Neste sentido, foi necessário proceder ao levantamento de diversas fontes, nomeadamente as intervenções parlamentares em plenário, a imprensa partidária, os programas eleitorais e dos congressos, a documentação diplomática, bem como outros documentos de instituições europeias e internacionais. Para complementar a análise foram também consultados artigos de imprensa publicados no Jornal de Notícias e no Diário de Notícias.

\subsection{Primeiro momento - Presidência Portuguesa das Comunidades Europeias}

Do mesmo modo que, internacionalmente, Portugal iniciava o período da Presidência Portuguesa das Comunidades Europeias no primeiro semestre de 1992, no plano interno o ponto de referência é a VI legislatura, que decorreu de 4 de novembro de 1991 a 26 de outubro de 1995, bem como parte da VII legislatura que sucedeu ao período atrás mencionado.

Nesta legislatura, o PSD formou Governo com maioria absoluta com o apoio dos seus 135 deputados eleitos. Na oposição, o PS obteve 72 deputados, a CDU (PCP-PEV) elegeu 17, o CDS fez-se representar por 5 parlamentares e o PSN elegeu um deputado. ${ }^{5}$

Em plena mudança na Europa de Leste, com especial incidência nos territórios que constituíam a Jugoslávia, a cooperação internacional portuguesa ganhou impacto aquando da primeira reunião conjunta Governo Português Comissão Europeia a 9 de janeiro de 1992. Segundo Rui Carp, deputado do $\mathrm{PSD}$, foram "encorajadoras as palavras elogiosas que o representante da ONU na mediação do conflito jugoslavo Sr. Cyrus Vance, fez à capacidade portu-

\footnotetext{
${ }^{5}$ Comissão Nacional de Eleições. Resultados eleitorais. Consultado a 17/05/2012. in <http:// eleicoes.cne.pt/raster/index.cfm?dia $=06 \&$ mes $=10 \& a n o=1991 \&$ eleicao $=$ ar $>$
} 
guesa para a mediação de conflitos internacionais, logo após a reunião realizada no Palácio das Necessidades com o ministro João de Deus Pinheiro". 6

A intervenção de Rui Carp havia surgido em resposta a Mário Tomé 7 , deputado independente eleito pelas listas da CDU, que questionou a posição do Governo português relativamente ao reconhecimento da Eslovénia e da Croácia, considerando este caminho como "necessário e urgente para minorar a complexidade e as dificuldades relativamente ao processo de paz". 8

João de Deus Pinheiro, à época, o Presidente do Conselho de Ministros dos Negócios Estrangeiros das Comunidades Europeias, embora reconhecendo a independência da Eslovénia e da Croácia, remetia o reconhecimento da Macedónia e da Bósnia-Herzegovina para uma discussão conjunta dos Doze ${ }^{9}$. Já Adriano Moreira, deputado do CDS, considerava que "um dos cuidados que os factos mostram ser importantes, traduzir-se-á em evitar que qualquer país dos Doze assuma uma política externa isolada, designadamente no caso da Jugoslávia." 10

Sobre este tema, é de referir que a 15 de janeiro de 1992 é enviado à Comissão Parlamentar dos Negócios Estrangeiros, por Álvaro Barreto, deputado do PSD e pertencente à Comissão dos Negócios Estrangeiros, Comunidades Portuguesas e Cooperação, o relatório Badinter relativo ao reconhecimento das novas repúblicas da Jugoslávia. ${ }^{11}$

Os pedidos de ajuda e colaboração, formalmente dirigidos pela Croácia, através do Institut Ruđer Bošković de Zagreb, ao então Primeiro-ministro Cavaco Silva, foram debatidos, segundo a correspondência analisada, nas reuniões dos grupos de trabalho, quer da Comissão Parlamentar de Assuntos Europeus, quer da dos Negócios Estrangeiros, Comunidades Portuguesas e Cooperação, com o objetivo de sensibilizar a consciência política, bem como a opinião pública. Destaca-se, assim, uma carta redigida a 25 de janeiro de

${ }^{6}$ Rui Carp, CEE: Presidência de Portugal, 10 de janeiro de 1992 in <http://www.parlamento. $\mathrm{pt} /$ Intervencoes/Paginas/DetalheIntervencao.aspx ?BID=33167>. (Consultado entre março e dezembro de 2011

${ }^{7}$ Centro de Documentação 25 de Abril - Universidade de Coimbra. Arquivo electrónico Mário Tomé. Consultado a 25/05/2012. in <http://www1.ci.uc.pt/cd25a/wikka.php?wakka=tome>.

${ }^{8}$ Mário Tomé, CEE: Presidência de Portugal, 10 de janeiro de 1992 in <http://www.parlamento.pt/Intervencoes/Paginas/DetalheIntervencao.aspx?BID=33167>. (Consultado entre março e dezembro de 2011

${ }^{9}$ Eduarda Ferreira, "Que se divida a Jugoslávia - mas não a coesão dos Doze”, Jornal de Notícias, 15/01/1992, Porto

${ }^{10}$ Eduarda Ferreira, "Conciliar é o desafio”, Jornal de Notícias, 01/01/1992, Porto

${ }^{11}$ Comissão Parlamentar dos Negócios Estrangeiros ao [Presidente da Assembleia da República,] 15/06/1992, in Arquivo Histórico Parlamentar 
1992, remetida por Maria Helena Ureña Prieto, na qual se podem ler informações relativas à situação dramática vivida na Croácia, procurando divulgar o reconhecimento da independência da República da Croácia e a necessidade de uma intervenção militar na Jugoslávia. A carta em questão foi enviada no seguimento de uma campanha internacional intitulada Help Croatia Now!, que procurava promover o reconhecimento da independência da Croácia e da Eslovénia.

Em fevereiro, segundo o jornal Povo Livre, havia sido decidido pelos Doze proceder ao reconhecimento da Eslovénia e da Croácia. Esta decisão sobre "a concretização do reconhecimento das outras duas repúblicas que manifestaram igualmente o desejo de se tornarem independentes - Macedónia e Bósnia-Herzegovina - está condicionada à resolução de problemas que ainda subsistem." 12

Apesar do reconhecimento da Bósnia-Herzegovina a 6 de abril de 1992 pelas Comunidades Europeias, não existe referência, no debate parlamentar, relativamente a esta matéria. No entanto, tal facto é abordado na imprensa partidária. No Povo Livre, questiona-se a definição de uma futura estrutura constitucional da Bósnia-Herzegovina, reconhecendo "dois princípios fundamentais: o respeito das actuais fronteiras daquela república e o respeito pela autonomia das diferentes comunidades". ${ }^{13}$ De igual modo, o Avante!, na sua secção "Internacional" aborda o acordo alcançado em Sarajevo no que respeita à independência da Bósnia-Herzegovina, após a quinta ronda de negociações ${ }^{14}$, bem como, uma semana depois, levanta questões em relação a um novo Estado jugoslavo agora com apenas duas das seis antigas repúblicas. ${ }^{15}$

A 25 de abril de 1992, a Embaixada da República Socialista Federativa da Jugoslávia remete à Comissão Parlamentar dos Negócios Estrangeiros uma carta, com o objetivo de apelar aos parlamentos dos Estados Membros da CSCE para renovar os esforços no sentido de encontrar o verdadeiro responsável pelo conflito na Bósnia-Herzegovina e criar uma "imagem rigorosa do que realmente se passa", alegando que a "regra de ouro dos deputados em qualquer país democrático é que a verdade está acima de tudo". É pedido para que sejam enviados observadores à região para verificar in loco que a República da Sérvia jamais havia cometido agressão à Bósnia-Herzegovina. Na carta, é solicitado apoio no recomeço e orientação da Conferência de Paz sobre a

\footnotetext{
12 "Nova fase da história da Europa", in Povo Livre 05/02/1992, Lisboa

13 "Mercado Interno: prioridade absoluta", in Povo Livre, 08/04/1992, Lisboa

14 "Independência da Bósnia-Herzegovina, in Avante!, 26/03/1992, Lisboa

15 “Jugoslávia em notícias", in Avante!, 02/04/1992, Lisboa
} 
Jugoslávia, reconhecendo, deste modo, que só através da mesma seria possível conseguir uma "solução legal, democrática e pacífica, numa base justa e durável". Na missiva, recusa-se a intervenção externa de tipo militar. A carta termina com a seguinte afirmação: "A Sérvia não contribuiu para o despoletar dos conflitos", sendo que a responsabilidade "não pode ser lançada sobre a Sérvia nem sobre as autoridades sérvias", afirmando a existência de "posições parciais e tendenciosas." 16

O Povo Livre é o primeiro órgão da imprensa partidária a noticiar a a 6 de maio de 1992, quando, no âmbito da Presidência Portuguesa das Comunidades Europeias, a Jugoslávia dominou a reunião dos ministros dos Negócios Estrangeiros dos Doze, em Guimarães, durante a qual, para a Bósnia-Herzegovina, "admitiram a hipótese de aumentar o número de observadores no local do conflito e de aconselhar a retirada das tropas do exército federal jugoslavo daquele território". ${ }^{17}$ Pouco mais de um mês depois, Cavaco Silva informa que a Presidência Portuguesa das Comunidades Europeia iria suspender as negociações entre os representantes das comunidades muçulmana, sérvia e croata, que haviam decorrido em maio, em Lisboa, bem como refere o embargo das Nações Unidas à Jugoslávia. O Avante!, menciona de igual modo a aplicação de sanções à Sérvia e Montenegro, ${ }^{18}$ e a Acção Socialista as conclusões do Conselho de Ministros de 15 de junho de 1992, dando conta do compromisso dos líderes da CE a "actuarem em uníssono como estipulado nas disposições da cooperação política europeia de 16 de Dezembro de 1991."19

Durante este período, os elogios por parte da comunidade internacional à Presidência Portuguesa das Comunidades Europeias foram, de uma forma geral, aceites pelo Parlamento, destacando-se, no entanto, as vozes discordantes do PCP, alegando que Portugal havia servido apenas os interesses dos países das Comunidades Europeias, procurando "os aplausos da Alemanha"20, segundo o deputado João Amaral, embora não fazendo referência direta ao conflito na ex-Jugoslávia.

${ }^{16}$ Embaixada da RSFJ à [Assembleia da República, Comissão Parlamentar dos Negócios Estrangeiros], 25/04/1992, in Arquivo Histórico Parlamentar.

17 “Jugoslávia dominou reunião de Guimarães, in Povo Livre, 06/05/1992, Lisboa

18 "Embargo total e ameaças de intervenção militar", in Avante!, 04/06/1992, Lisboa

19 "Jugoslávia", in Acção Socialista, 18/06/1992, Lisboa

${ }^{20}$ João Amaral, Presidência Portuguesa da Comunidade Europeia, 4 de julho de 1992 in $<$ http://www.parlamento.pt/Intervencoes/Paginas/DetalheIntervencao.aspx ?BID=10624>. (Consultado entre março e dezembro de 2011). 


\subsection{Segundo momento - As primeiras vozes discordantes}

Após o período da Presidência Portuguesa das Comunidades Europeias, surge pela primeira vez, descrito no Avante! uma crítica à intervenção europeia relativamente à Jugoslávia, classificando o cessar-fogo assinado em Londres como o trigésimo-nono "patrocinado pela $\mathrm{CE}$, e os falhanços que nesse domínio se têm vindo a suceder, testemunham não apenas a gravidade dos problemas, a ultrapassar, mas também de que há interesses em jogo em que se aposta forte na via militar." ${ }^{21}$

A 13 de agosto de 1992, o PCP considerou o conflito como uma ameaça para a humanidade, tendo emitido uma nota da Comissão Política do partido, criticando as declarações belicistas dos governos das grandes potências imperialistas, designadamente os Estados Unidos da América, a Grã-Bretanha, a França e a Alemanha, bem como instituições internacionais como a NATO, UEO e o Conselho de Segurança das Nações Unidas, "visando impressionar a opinião pública e criar condições favoráveis a uma escalada militar intervencionista na Jugoslávia.” O PCP alertava que esta tragédia serviria para as "pretensões de instaurar uma «nova ordem internacional» imperialista na qual seriam de novo as «grandes potências» a impor pela força, incluindo a guerra, a sua vontade a todos os povos do mundo.” 22 A convicção é de que, além de ilegítima, esta intervenção contribuiria para o agravamento interno do conflito na Bósnia-Herzegovina e na Jugoslávia.

É nesta base que o PCP aproveita para reforçar o «Não» ao Tratado de Maastricht, criticando duramente Jacques Delors, então Presidente da Comissão Europeia, que viria, na opinião daquele partido, confirmar os perigos de uma política europeia externa e de segurança comum, bem como as declarações produzidas no dia anterior por João Cravinho, deputado socialista no Parlamento Europeu, convidando o Partido Socialista a "definir claramente a sua posição e a associar-se com todos os democratas e amantes da paz, aos esforços para impedir uma escalada militar intervencionista e encontrar uma solução política negociada para o dramático conflito jugoslavo". O último ponto desta nota foca a possibilidade de uma intervenção militar portuguesa na Jugoslávia, no âmbito da UEO, opondo-se o PCP à participação e envolvimento das Forças Armadas Portuguesas, reclamando que o Governo português colocasse "imediatamente termo à sua política ambígua e seguidista em

\footnotetext{
21 "Jugoslávia", in Avante!, 23/07/1992, Lisboa

22 "Uma ameaça para a humanidade", in Avante!, 13/08/1992, Lisboa
} 
relação ao dramático conflito jugoslavo" ${ }^{23}$, e assumisse claramente as suas responsabilidades perante o povo português.

A posição do PCP está claramente definida na resolução política aprovada no XIV Congresso do partido, realizado nos dias 4, 5 e 6 de dezembro de 1992 em Almada, podendo ler-se o seguinte: "É urgente encontrar soluções políticas que impeçam ódios antigos e novos, soprados, por nacionalismos reacionários e por potências estrangeiras, de continuar o dramático ciclo de destruição e morte que se instalou na ex-Jugoslávia. As nações que compunham este país acabarão por confirmar que é do seu interesse uma política de cooperação estreita com base numa real igualdade de direitos. Neste sentido, qualquer intervenção militar externa apenas contribuiria para levar ainda mais longe e tornar ainda mais explosivo o conflito". ${ }^{4}$

Paralelamente, na Comissão Parlamentar dos Negócios Estrangeiros, é discutido o relatório enviado pela Embaixada da República Federal da Jugoslávia, sobre a manipulação internacional mediática, antevendo uma intervenção militar, com destaque para o papel dos média alemães e americanos na dissolução da Jugoslávia.$^{25}$ Neste período, os trabalhos da Comissão debatiam, sobretudo, a ajuda humanitária à região, atendendo aos múltiplos pedidos de colaboração através de assistência médica, destacando-se o papel da Cáritas Portuguesa, da Assistência Médica Internacional (AMI), da Cruz Vermelha e de outras Organizações Não Governamentais, conforme o relatório enviado por Leonor Ribeiro da Silva, do Gabinete do Ministério dos Negócios Estrangeiros ao Gabinete do Secretário de Estados dos Assuntos Parlamentares, Manuel Tabau, sobre a ajuda humanitária à Jugoslávia. ${ }^{26}$

Numa carta datada de 20 de dezembro de 1992, dirigida ao Presidente da Assembleia da República de António Maria Pereira, então Presidente da Comissão Parlamentar dos Negócios Estrangeiros, discute-se o possível envio de observadores das Nações Unidas e da Comunidade Europeia para a fiscalização das eleições, a nível federal e republicano, nas Repúblicas da Sérvia e Montenegro ${ }^{27}$ no âmbito da cooperação política europeia. A des-

23 "Uma ameaça para a humanidade", in Avante!, 13/08/1992, Lisboa

${ }^{24}$ Partido Comunista Português, Resolução Política XIV Congresso do PCP. 6 de Dezembro de 1992 in <http://www.pcp.pt/resolu\%C3\%A7\%C3\%A3o-pol\%C3\%ADtica-xiv-congresso-dopcp $>$. (Consultado a 15/10/2011)

${ }^{25}$ Embaixada da RFJ à [Assembleia da República, à Comissão Parlamentar dos Negócios Estrangeiros], 20/10/1992, in Arquivo Histórico Parlamentar

${ }^{26}$ Leonor Ribeiro da Silva à [Assembleia da República, ao Gabinete do Secretário de Estado dos Assuntos Parlamentares], 23/11/1992, in Arquivo Histórico Parlamentar

${ }^{27}$ As referidas eleições decorreram no dia 20 de dezembro de 1992. 
tacar, a nota elaborada pela Adjunta Diplomática Ana M. R. Silva, onde se pode ler o seguinte: "Não me parece oportuno o envio de observadores. As eleições serão ganhas, provavelmente, por Slobodan Milošević. A presença de observadores significaria o reconhecimento da situação que até agora se vive naquelas repúblicas." ${ }^{28}$ António Maria Pereira desaconselhou, assim, o envio de observadores para fiscalizar as eleições na República da Sérvia e do Montenegro, reiterando que seria melhor, para além das Nações Unidas, ser a Comunidade Europeia a enviar os observadores. A coordenação dessa ação seria assegurada pelo ODHIR (Office for Democratic Institutions and Human Rights) da CSCE. ${ }^{29}$

A este título, o Conselho Europeu de Edimburgo, realizado nos dias 11 e 12 de dezembro de 1992, promoveu a tomada de conhecimento das violações dos direitos humanos na Bósnia-Herzegovina, tendo emitido uma declaração oficial relativa ao tratamento de mulheres muçulmanas na antiga Jugoslávia. O Conselho condenou formalmente as violações sistemáticas de mulheres, considerando o seguinte: "o Conselho Europeu condena veementemente estes actos de inqualificável brutalidade, que se inserem numa estratégia deliberada para aterrorizar a comunidade muçulmana da Bósnia-Herzegovina, destinada a alcançar o objetivo da depuração étnica", prometendo que seriam julgados "os responsáveis por todos estes crimes contra a Humanidade." Mais ainda, o Conselho condenou a existência de campos de detenção, exigindo o seu encerramento imediato. ${ }^{30}$

O relatório confirmou "que um número aterrador de mulheres muçulmanas tinha sofrido violações e que tal prática continuava; que pelo menos parte das violações eram cometidas de forma particularmente sádica para infligir às vítimas a máxima humilhação, tendo muitas mulheres, em particular crianças, morrido durante ou após as violações; que múltiplas violações foram praticadas contra mulheres detidas em campos ou em pequenos centros localizados em casas, restaurantes, postos de polícia, etc., muitos deles especificamente destinados a esse fim; que sendo impossível avaliar quantas gravidezes resul-

${ }^{28}$ Chefe do Gabinete do Ministro dos Negócios Estrangeiros - Álvaro Mendonça e Moura ao [Presidente da Assembleia da República], 11/12/1992, in Arquivo Histórico Parlamentar

${ }^{29}$ Comissão Parlamentar dos Negócios Estrangeiros ao [Presidente da Assembleia da República], 15/12/1992, in Arquivo Histórico Parlamentar

${ }^{30}$ A declaração relativa à ex-Jugoslávia pode ser consultada no sítio de Internet da Comissão Europeia. Conselho Europeu de Edimburgo - 11/12 de Dezembro de 1992: Conclusões da Presidência.. Consultado a 22/05/2012. in <http://europa.eu/rapid/pressReleasesAction.do?refe rence $=$ DOC $/ 92 / 8 \&$ format $=$ HTML \&aged $=0 \&$ language $=\mathrm{PT} \&$ guiLanguage $=\mathrm{en}>$ 
taram das violações, muitas das mulheres não desejavam conservar os filhos concebidos em tais circunstâncias, o que levanta a questão da adoção"31.

O Partido Socialista, através do seu jornal Acção Socialista, abordou a temática da Jugoslávia, condenando "os primeiros campos de concentração (na Europa) após 1945"32, e realçando que, nos Estados Unidos da América, a nova administração Clinton considerava que "uma das suas prioridades, em matéria de política externa seria a Bósnia-Herzegovina." ${ }^{33}$ Em contraponto, o PCP alerta para que "os Estados Unidos da América, a França e a Grã-Bretanha afirmam consensos e plano de intervenção militar"34, acusando que "a lógica da guerra continua a sobrepor-se à lógica da paz" ${ }^{35}$, dando conta da imposição de soluções militares para a resolução do conflito.

O jornal Acção Socialista foca a reunião da Direção da Internacional Socialista das Mulheres, realizada em Atenas a 6 e 7 de fevereiro, onde foram adotadas duas resoluções, uma respeitante à "situação das mulheres nos sistemas económicos em evolução" e outra referente aos "maus tratos e violências cometidas contra as mulheres e crianças na ex-Jugoslávia". ${ }^{36}$

\subsection{Terceiro momento - As primeiras intervenções no Parlamento}

O conflito na ex-Jugoslávia é comentado no Parlamento, por iniciativa da deputada do Partido Social Democrata, Leonor Beleza ${ }^{37}$, a 19 de fevereiro de 1993.

A declaração da deputada evidencia-se pelo discurso emocional, procurando chamar à atenção e sensibilizar, não apenas a opinião pública portuguesa, mas, principalmente, a Assembleia da República e os seus colegas parlamentares. As violações sistemáticas de mulheres e crianças, na sua grande maioria bósnias muçulmanas, e as deslocações massivas dos territórios foram alvo de debate, denunciando a existência de uma "estratégia de limpeza étnica

${ }^{31}$ A título exemplificativo, a produção cinematográfica de Zbanic, Jasmila. (2006). Grbavica, Coop 99 et al. Alemanha, Áustria Bósnia e Croácia., aborda a questão das violações sistemáticas de mulheres muçulmanas e gravidezes indesejadas.

32 "A Jugoslávia - a ferida”, in Acção Socialista, 07/01/1993, Lisboa

33 "O pesadelo da Bósnia", in Acção Socialista, 29/01/1993, Lisboa

34 "Jugoslávia", in Avante!, 07/01/1993, Lisboa

35 "Jugoslávia", in Avante!, 11/02/1993, Lisboa

36 "Internacional Socialista das Mulheres", in Acção Socialista 11/03/1993, Lisboa

${ }^{37}$ Para aceder à biografia de Leonor Beleza, ver informações em Assembleia da República. Leonor Beleza. Consultado entre março e dezembro de 2011. in <http://www.parlamento.pt/ DeputadoGP/Paginas/Biografia.aspx?BID=114> 
destinada a aterrorizar os muçulmanos e a fazê-los deixar a sua terra." 38 Da mesma forma, Leonor Beleza condenou a incapacidade da comunidade internacional face a uma guerra que considerava cruel. Aparentemente, as conferências internacionais, os relatórios e as sanções pareciam ser incapazes de pôr um fim definitivo ao conflito.

Estudo das intervenções no Parlamento relativamente ao conflito na Bósnia-Herzegovina no período 1992-1995

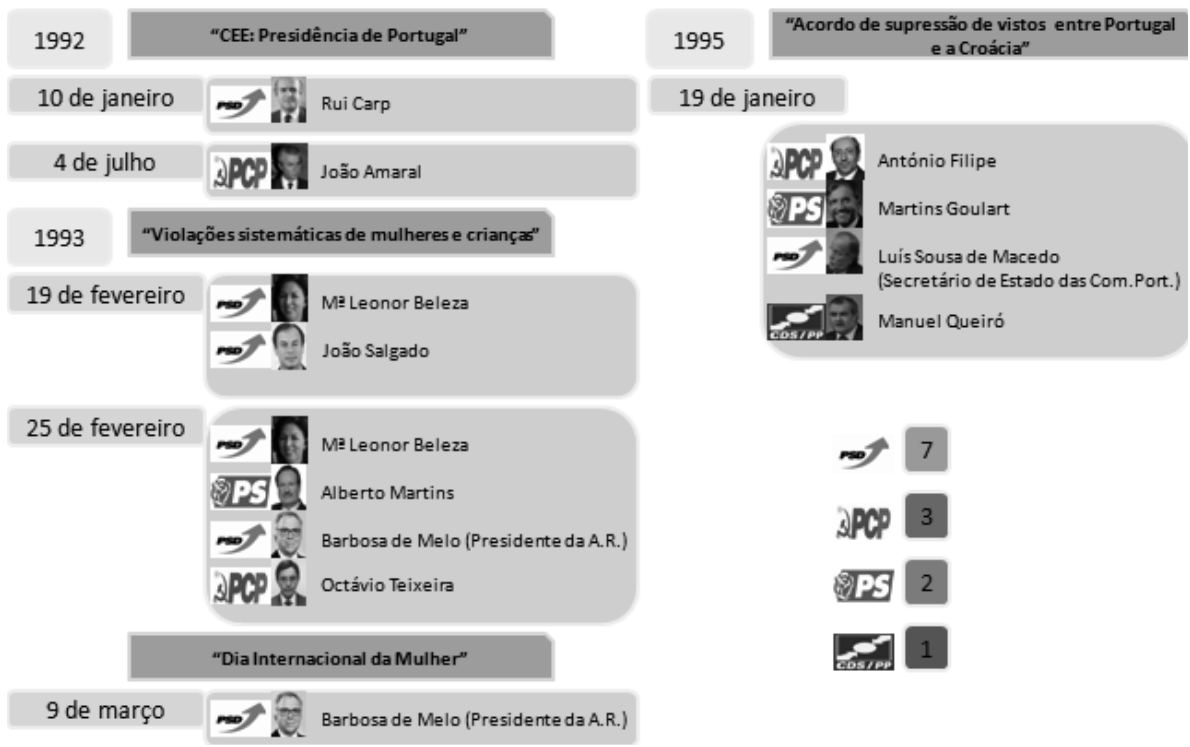

Figura 1 - Estudo das intervenções no Parlamento relativamente ao conflito na Bósnia-Herzegovina no período 1992-1995 (esquema realizado pela autora)

No ano de 1993, em fevereiro, período durante o qual se intensificaram os ataques bósnios sérvios na Bósnia-Herzegovina, a deputada interveio por duas vezes em defesa dos direitos humanos, propondo à Assembleia da República

${ }^{38}$ Leonor Beleza, Condenação das violações dos direitos humanos na ex-Jugoslávia, 19 de fevereiro de 1993. in <http://app.parlamento.pt/DARPages/DAR_FS.aspx?Tipo=DAR+ $\mathrm{I}+\mathrm{s} \% \mathrm{C} 3 \% \mathrm{~A} 9$ rie $\& \mathrm{tp}=\mathrm{D} \&$ Numero $=40 \&$ Legislatura $=\mathrm{VI} \&$ SessaoLegislativa $=2 \& \mathrm{Data}=1993-$ 02-19\&Paginas $=1459-1461 \&$ PagIni $=0 \&$ PagFim $=0 \&$ Observacoes $=\&$ Suplemento $=. \&$ PagAct ual=0\&pagFinalDiarioSupl=\&idpag $=\&$ idint $=35119 \&$ idact $=\& i d d e b=>$. $($ Consultado entre março e dezembro de 2011). 
"um voto de denúncia e condenação de práticas selvagens e atrozes contra mulheres e crianças no território da ex-Jugoslávia, com especial relevo para a região da Bósnia-Herzegovina" 39 , capaz de contribuir para a manutenção de um ambiente minimamente tolerável e pacífico um pouco por toda a região balcânica, pondo fim à "tortura, morte e às humilhações pelas formas mais abomináveis".

$\mathrm{Na}$ ótica de Leonor Beleza, Portugal, um país onde existe um sistema de defesa dos direitos, liberdades e garantias, deveria aberta e livremente discutir o conflito na ex-Jugoslávia. A deputada acrescentou que já a 11 de setembro de 1992 o Comité de Ministros do Conselho da Europa "exprimia a sua mais viva inquietação face ao conflito na antiga Jugoslávia" onde eram "violados quotidianamente, com a maior brutalidade, os direitos humanos e os outros princípios da Organização, causando sofrimentos indescritíveis no plano humano." ${ }^{40}$ Referiu, ainda, a existência de campos de detenção ou de trabalho e os campos unicamente para mulheres, justificando assim o envio de organizações humanitárias para o terreno.

A deputada social-democrata parecia estar segura relativamente ao que ia sendo feito em matéria de ajuda humanitária na ex-Jugoslávia, em particular na Bósnia-Herzegovina. A mesma mencionou que, a 18 de dezembro de 1992, o Conselho de Segurança tinha apoiado incondicionalmente ${ }^{41}$ a iniciativa do Conselho Europeu de Edimburgo, no âmbito da proteção das mulheres e crianças muçulmanas, através do envio de uma missão ${ }^{42}$ ao local, conse-

39 "Direitos Humanos: Voto contra as atrocidades na Bósnia-Herzegovina", in Povo Livre, 24/02/1993, Lisboa

${ }^{40}$ Leonor Beleza, Condenação das violações dos direitos humanos na ex-Jugoslávia, 19 de fevereiro de 1993. in <http://app.parlamento.pt/DARPages/DAR_FS.aspx?Tipo=DAR+ $\mathrm{I}+\mathrm{s} \% \mathrm{C} 3 \% \mathrm{~A}$ 9rie $\& \mathrm{tp}=\mathrm{D} \&$ Numero $=40 \&$ Legislatura $=\mathrm{VI} \&$ SessaoLegislativa $=2 \& \mathrm{Data}=1993-$ 02-19\&Paginas $=1459-1461 \&$ PagIni $=0 \&$ PagFim $=0 \&$ Observacoes $=\&$ Suplemento $=. \&$ PagAct ual $=0 \&$ pagFinalDiarioSupl $=\& i d p a g=\& i d i n t=35119 \&$ idact $=\& i d d e b=>$. $($ Consultado entre março e dezembro de 2011).

${ }^{41}$ Resolução 798 (1992) adotada pelo Conselho de Segurança relativa à prática de violações sistemática e existência de campos para mulheres in Security Council Resolutions - $1992<\mathrm{http} / /$ daccess-dds-ny.un.org/doc/UNDOC/GEN/N92/828/82/IMG/N9282882.pdf?OpenElement>. (Consultado a 22/05/2012).

${ }^{42}$ A referida missão, chefiada por Anne Warburton e Simone Veil, decorreu, numa primeira fase, entre 18 e 24 de dezembro de 1992, deslocando-se a Zagreb. "O domínio da assistência médica e humanitária, facilitação de vistos e de acolhimento por parte dos países da Comunidade e da necessidade de preservar e recolher as fontes de informação sobre o que se estava a passar" constituiu o conjunto de ações levadas a cabo na Bósnia-Herzegovina. Informação retirada a partir da intervenção da deputada Leonor Beleza, in <http:/www.parlamento.pt/Intervencoes/ Paginas/DetalheIntervencao.aspx ?BID=3511>. (Consultado entre março e dezembro de 2011). 
guindo, deste modo, um número considerável de testemunhas para o julgamento dos crimes.

A intervenção de Leonor Beleza foi bastante aplaudida, destacando-se vozes de apoio como as de Carlos Coelho, igualmente deputado do PSD, ou até de José Magalhães e Almeida Santos, deputados do Partido Socialista, congratulando a deputada Leonor Beleza pela qualidade do seu discurso, empenho, e solidariedade, bem como pela proposta de voto que foi sujeita a votação.

Leonor Beleza, tendo em consideração que "a solidariedade que sentimos para com seres humanos tão violentamente desapossados da sua dignidade e tão indelevelmente marcados por sofrimentos que só somos capazes de imaginar" ${ }^{43}$, conseguiu promover a tomada de posição por parte dos parlamentares face ao conflito, optando pelo intervencionismo formal e oficial, com o objetivo de assistir humanitária e medicamente as vítimas da guerra e promover a solidariedade e acolhimento por parte da população portuguesa.

No seguimento da intervenção da deputada do PSD, o Secretário da Mesa da Assembleia da República, João Salgado ${ }^{44}$, eleito pelo PSD, procedeu à leitura

Quanto à segunda fase da missão, de 18 a 26 de janeiro de 1993, destaca-se a participação de Regina Tavares da Silva, assessora especial da Comissão Governamental para a Igualdade e os Direitos das Mulheres desde 1992. Dessa missão resultou um relatório que confirmava e fundamentava as violações sistemáticas de mulheres e crianças (a partir dos 6/7 anos). A lista de missões pela comissão de peritos da Organização das Nações Unidas encontra-se disponível no

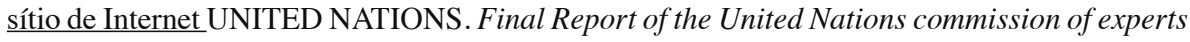
established pursuant to Security Council resolution (1992). Consultado a 05/12/ 2011. in <http:// www.law.depaul.edu/centers_Institutes/ihrli/downloads/Annex_IB.pdf>

${ }^{43}$ A referida missão, chefiada por Anne Warburton e Simone Veil, decorreu, numa primeira fase, entre 18 e 24 de dezembro de 1992, deslocando-se a Zagreb. "O domínio da assistência médica e humanitária, facilitação de vistos e de acolhimento por parte dos países da Comunidade e da necessidade de preservar e recolher as fontes de informação sobre o que se estava a passar" constituiu o conjunto de ações levadas a cabo na Bósnia-Herzegovina. Informação retirada a partir da intervenção da deputada Leonor Beleza, in <http:/www.parlamento.pt/Intervencoes/ Paginas/DetalheIntervencao.aspx ?BID=3511>. (Consultado entre março e dezembro de 2011). Quanto à segunda fase da missão, de 18 a 26 de janeiro de 1993, destaca-se a participação de Regina Tavares da Silva, assessora especial da Comissão Governamental para a Igualdade e os Direitos das Mulheres desde 1992. Dessa missão resultou um relatório que confirmava e fundamentava as violações sistemáticas de mulheres e crianças (a partir dos 6/7 anos). A lista de missões pela comissão de peritos da Organização das Nações Unidas encontra-se disponível no sítio de Internet UNITED NATIONS. Final Report of the United Nations commission of experts established pursuant to Security Council resolution (1992). Consultado a 05/12/ 2011. in <http:// www.law.depaul.edu/centers_Institutes/ihrli/downloads/Annex_IB.pdf>

${ }^{44}$ Para aceder à biografia de João Salgado, ver informação disponível em Assembleia da República. João Salgado. Consultado entre março e dezembro de 2011. in <http://www.parlamento.pt/DeputadoGP/Paginas/Biografia.aspx ?BID=63> 
do voto $\mathrm{n}$. 63/VI relativo à condenação das violações dos direitos humanos na ex-Jugoslávia, elaborado pela Comissão de Assuntos Constitucionais, Direitos, Liberdades e Garantias. Este voto consistiu na denúncia das "deslocações forçadas de populações civis, a prática sistemática de torturas, homicídios e humilhações de toda a ordem" 45 . Para isso, foram considerados testemunhos que atestavam as "violências praticadas como fazendo parte de uma estratégia deliberada de limpeza étnica", bem como as "violações e abusos sexuais utilizados como armas de guerra, detendo mulheres e crianças bósnias muçulmanas" e "obrigadas a levar a termo a gravidez daí resultante, em insuportáveis condições de mutilação psicológica e humana." "46. João Salgado considerou ser necessário condenar as atrocidades na ex-Jugoslávia, sendo necessário promover "uma onda de revolta na consciência democrática dos Europeus" 47 , tendo como pontos de referência a Convenção de Genebra sobre a Proteção das Vítimas de Guerra (12 de agosto de 1949$)^{48}$ e a Carta das Nações Unidas, bem como a Declaração sobre a Proteção de Mulheres e Crianças em Situações de Emergência e em Conflitos Armados (14 de dezembro 1974) ${ }^{49}$.

No seguimento da sua intervenção no dia 19 de fevereiro de 1993, a deputada voltou, uma semana depois, a pedir a palavra, com o objetivo de justificar a posição do PSD relativamente ao voto, elaborado pela Comissão de Assuntos Constitucionais, Direitos, Liberdades e Garantia. Tal voto havia sido preparado a pedido da então Presidente do Bundestag, Rita Süssmuth ${ }^{50}$, no

${ }^{45}$ João Salgado, Condenação das violações dos direitos humanos na ex-Jugoslávia. 19 de fevereiro de 1993 in <http://www.parlamento.pt/Intervencoes/Paginas/DetalheIntervencao. aspx?BID=134575>. (Consultado entre março e dezembro de 2011).

46 "Direitos Humanos: Voto contra as atrocidades na Bósnia-Herzegovina", in Povo Livre, 24/02/1993, Lisboa

${ }^{47}$ Ibid.

${ }^{48} \mathrm{O}$ texto oficial da Convenção de Genebra sobre a Proteção das Vítimas de Guerra encontra-se disponível no sítio de Internet do Comité Internacional da Cruz Vermelha - International Committee of the Red Cross. Convention (III) relative to the Treatment of Prisoners of War, Geneva, 12 August 1949. Consultado a 23/01/2012. in <http://www.icrc.org/ihl.nsf/ FULL/375?OpenDocumentv>

${ }^{49}$ A declaração oficial encontra-se disponível no sítio de Internet do Gabinete de Documentação e Direito Comparado. Declaração sobre a Protecção de Mulheres e Crianças em Situações de Emergência e de Conflito Armado. Consultado a 23/01/2012. in <http://direitoshumanos.gddc. pt/DireitosHumanos/3_4/IIIPAG3_4_6.htm>

${ }^{50}$ Rita Süssmuth foi membro do Bundestag de 1987 a 2002, tendo assumido a presidência do Bundestag até ao ano de 1998, após a demissão de Philipp Jenninger (1988). Para mais informações aceder ao sítio de Internet do Deutscher Bundestag. Rita Sïssmuth. Consultado a 23/01/2012. in <http://www.bundestag.de/bundestag/praesidium/bundestagspraesidenten_ seit_1949/suessmuth.html> 
qual se encontram formalmente contempladas várias condenações por parte da Assembleia da República face aos "comportamentos e às práticas de uma barbárie inultrapassável” na ex-Jugoslávia.

A Assembleia da República condenou pública e expressamente, os "atentados contra os direitos humanos das populações civis na ex-Jugoslávia”, bem como a "purificação étnica que lembra os mais vergonhosos momentos da história da Europa." Mais ainda, a Assembleia da República considerou a necessidade por parte das Comunidades Europeias em facilitar a concessão de asilo assim como auxílio médico e humanitário, bem como simplificar "os mecanismos de concessão de vistos de acesso a territórios de acolhimento." 51

No seguimento da intervenção da deputada Leonor Beleza (PSD), o deputado socialista Alberto Martins ${ }^{52}$ interveio em plenário, no intuito de dar a conhecer a posição do Grupo Parlamentar Socialista relativamente às violações dos direitos humanos na ex-Jugoslávia. Alberto Martins mencionou pela primeira vez os sérvios como sendo os culpados pelas violações sistemáticas. Tratou-se de uma intervenção relativamente simples e curta, que assentou na condenação formal e oficial das violações, "quaisquer que sejam, na ex-Jugoslávia". ${ }^{33}$ Alberto Martins considerou positivas as decisões do Conselho de Segurança da ONU, sobretudo, no que respeita à criação de um tribunal destinado ao julgamento e condenação de crimes de guerra ${ }^{54}$.

Relativamente ao Partido Comunista Português, Octávio Teixeira interveio com o objetivo de justificar o voto de abstenção do PCP quanto ao voto de denúncia acima referido. O PCP solicitava, essencialmente, que todas as violações e detenções de mulheres e crianças na Bósnia-Herzegovina fossem oficial e formalmente condenadas pela Assembleia da República, e não apenas as que estavam sendo praticadas tendo como principais alvos as vítimas de ori-

${ }^{51}$ Leonor Beleza, Violações dos direitos humanos na ex-Jugoslávia. 25 de fevereiro de 1993 in <http://www.parlamento.pt/Intervencoes/Paginas/DetalheIntervencao.aspx?BID=34805>. (Consultado entre março e dezembro de 2011).

${ }^{52}$ Assembleia da República. Alberto Martins. Consultado 11/10/2011. in <http://www. parlamento.pt/DeputadoGP/Paginas/Biografia.aspx?BID=462>

${ }^{53}$ Alberto martins, Violações dos direitos humanos na ex-Jugoslávia. 25 de fevereiro de 1993 in <http://www.parlamento.pt/Intervencoes/Paginas/DetalheIntervencao.aspx?BID=34804>. (Consultado entre março e dezembro de 2011).

${ }^{54}$ O Tribunal Internacional para a Ex-Jugoslávia foi criado em 1993 por iniciativa das Nações Unidas, com o objetivo de julgar indivíduos que deliberadamente contribuíram para a limpeza étnica de determinadas comunidades e/ou etnias na região da ex-Jugoslávia. Para mais informação, consultar o sítio de Internet International Criminal Tribunal for the Former Yugoslavia. About the ICTY. Consultado a 09/12/2011. in <http://www.icty.org/sections/AbouttheICTY> 
gem muçulmana. ${ }^{55}$ Evidencia-se, portanto, por parte do PCP, uma tomada de posição mais global no que respeita à etnia das vítimas, conforme as sugestões então elaboradas, refletindo-se nas propostas de alteração igualmente levadas a votação.

Procedeu-se então à votação da proposta de alteração do PCP, propondo a substituição do parágrafo da versão original, onde se lia "(A Assembleia da República) Condena vivamente as detenções e violações sistemáticas de mulheres e crianças muçulmanas na Bósnia", propondo, "Condena vivamente as detenções e violações sistemáticas de mulheres e crianças na Bósnia, praticados por todas as partes em conflito." 56 Todavia, a votação registou uma rejeição, com os votos contra do PSD, do PS e do CDS, e os votos a favor do PCP, de Os Verdes e dos deputados independentes João Corregedor da Fonseca, bem como de Mário Tomé.

Foi necessário elaborar uma nova proposta de alteração à votação no ponto em que propunha o aditamento de um novo parágrafo: "(A Assembleia da República) Considera que os atentados contra os direitos humanos, incluindo as atrocidades praticadas contra mulheres e crianças, só serão plenamente erradicados com uma solução política para o conflito na ex-Jugoslávia e exorta todas as partes a que devolvam efetivos esforços que conduzam ao rápido fim da guerra".

Quanto à votação do Voto 63-CACDLG, o mesmo foi aprovado com votos a favor do PSD, do PS, do CDS, de Os Verdes e do deputado independente Mário Tomé. Registaram-se as abstenções por parte do PCP, bem como do deputado independente João Corregedor da Fonseca. De realçar a diferença de sentido de voto na bancada da CDU, pois, contrariamente ao PCP, este texto foi aprovado pelos deputados do PEV e pelo deputado independente Mário Tomé, eleitos por esta coligação.

55 Octávio Teixeira, Violações dos direitos humanos na ex-Jugoslávia, 25 de fevereiro de 1993 in <http://www.parlamento.pt/Intervencoes/Paginas/DetalheIntervencao.aspx?BID=34806>. (Consultado entre março e dezembro de 2011). Para aceder à sua biografia, ver informação disponível em Assembleia da República. Octávio Teixeira. Consultado entre março e dezembro de 2011. in <http://www.parlamento.pt/DeputadoGP/Paginas/Biografia.aspx?BID=222>.

${ }^{56}$ Presidente da Mesa da Assembleia da República, Violações dos direitos humanos na ex-Jugoslávia. 25 de fevereiro de 1993 in <http://www.parlamento.pt/Intervencoes/Paginas/ DetalheIntervencao.aspx?BID=134576>. (Consultado entre março e dezembro de 2011). 
As condenações dos direitos humanos na ex-Jugoslávia constituíram, de facto, o ponto fulcral do texto final, exortando a todas as partes "que desenvolvam efectivos esforços que conduzam ao rápido fim da guerra." 57

O Dia Internacional da Mulher foi celebrado a 8 de março na Assembleia da República, tendo sido discutido a pertinência de alguns diplomas legislativos em matéria de igualdade de direitos e discriminação. ${ }^{58}$

Foi um dia reservado não apenas ao debate e reflexão do papel da mulher na sociedade, mas também à violência de que continua sendo alvo. Deu-se especial relevância às vítimas da indústria do sexo, da guerra, de violação, sendo dado como exemplo o conflito da Bósnia-Herzegovina, pelo que todos os dias notícias de violações sistemáticas e em série inundavam as principais cadeias televisivas. Barbosa de Melo, Presidente da Assembleia da República, considerou sua responsabilidade relembrar tal situação, bem como alertar, exigir e comprometer toda a Assembleia, afirmando "que a capacidade de olhar com distância para o sofrimento de outros povos e de outras mulheres, onde quer que se encontrem, não pode impedir à Assembleia de deter o seu olhar na própria realidade do seu país". ${ }^{59}$

\subsection{Quarto momento - $O$ debate prossegue na imprensa partidária}

No seguimento da análise da documentação parlamentar, de salientar que a Embaixada da República Federal da Jugoslávia em Portugal, contactou novamente a Assembleia da República, a 24 de abril de 1993, no intuito de dar a conhecer os pontos discutidos na Assembleia Federal (Sérvia e Montenegro) relativamente às sanções impostas ao seu país pelo Conselho de Segurança das Nações Unidas. ${ }^{60}$ Num artigo publicado pelo jornal Avante! era considerado que existiam "elementos que hão de ser encontrados dentro da própria Jugoslávia e outros decorrentes de uma nova situação internacional, em que a Alemanha unificada assume um novo papel europeu e mundial, e foi a primeira responsável pelo desmembramento da Jugoslávia, ao reconhecer,

${ }^{57}$ Presidente da Mesa da Assembleia da República, Violações dos direitos humanos na ex-Jugoslávia. 25 de fevereiro de 1993 in <http://www.parlamento.pt/Intervencoes/Paginas/ DetalheIntervencao.aspx?BID=134576>. (Consultado entre março e dezembro de 2011).

${ }^{58}$ Presidente da Mesa da Assembleia da República, Dia Internacional da Mulher. 9 de março de 1993 in <http://www.parlamento.pt/Intervencoes/Paginas/DetalheIntervencao. aspx?BID=134796>. (Consultado entre março e dezembro de 2011).

${ }^{59}$ Ibid.

${ }^{60}$ Embaixada da RFJ à [Assembleia da República, à Comissão Parlamentar dos Negócios Estrangeiros], 24/04/1993, in Arquivo Histórico Parlamentar 
unilateralmente, a independência da Croácia e da Eslovénia, impondo-o às Comunidades Europeias". Considera, igualmente, que "o «modelo socialista autogestionário» da Jugoslávia continha dentro de si muitos dos elementos perversos do «modelo» do socialismo da URSS, sendo certo e também digno de registo que durante a Presidência de Tito não houve conflitos acentuados entre as diferentes nacionalidades." 61

O desenrolar do conflito foi noticiado tanto pela Acção Socialista como pelo Avante!, nomeadamente o plano de paz Vance-Owen, assinado "inesperadamente por Karadžićc" e onde, dizia o PS, os Estados Unidos da América afirmaram a sua disponibilidade para "participar numa força multinacional de paz para a Bósnia, caso o parlamento servo-bósnio [SIC] aprove o tratado"62. No entanto, segundo o PCP, a rejeição deste plano, apesar do apelo por parte dos responsáveis jugoslavos, contribuiu para as "medidas mais duras decretadas pelo Conselho de Segurança contra qualquer país desde o bloqueio total aplicado ao Iraque aquando da invasão do Kuwait", e, "dentro da lógica maniqueísta de que seriam os sérvios os únicos responsáveis da guerra sangrenta que devasta a Bósnia-Herzegovina." ${ }^{63}$

Com efeito, enquanto a Acção Socialista classificava o referendo motivado após a apresentação do plano de paz, pressupondo a divisão da Bósnia-Herzegovina em dez regiões semi-autónomas, com o apoio da ONU, como tendo sido o causador do afundamento do plano Vance-Owen ${ }^{64}$, o Avante! publicava uma nota da Comissão Política do PCP onde criticava "a resolução n. ${ }^{\circ} 820$ do Conselho de Segurança das Nações Unidas sobre o conflito armado na Bósnia-Herzegovina, impondo à Federação Jugoslava (Sérvia e Montenegro) um embargo jamais utilizado contra qualquer outro país, constituindo um novo e perigoso passo na escalada em direcção a uma intervenção militar externa, que a todo o custo é imperioso evitar" ${ }^{\prime 5}$. O PCP considerava que "a Federação Jugoslava exerce hoje um importante papel pacificador e moderador quanto ao conflito bósnio", e, referindo-se a anteriores declarações, realçava que, "perante a extraordinária complexidade da situação, só uma persistente e firme política de negociações entre as diversas partes em confronto, com espírito de imparcialidade" poderia facilitar o fim dos horrores que vivem os povos que integravam a ex-Jugoslávia. De igual modo, o PCP

\footnotetext{
61 “Jugoslávia”, in Avante!, 25/02/1993, Lisboa

62 "Assinado Acordo Bósnia", in Acção Socialista, 6/05/1993, Lisboa

63 "Conselho de Segurança agrava sanções", in Avante!, 29/04/1993, Lisboa

64 "Bósnia: referendo afunda plano Vance-Owen", in Acção Socialista, 20/05/1993, Lisboa

65 "O conflito na ex-Jugoslávia", in Avante!, 06/05/1993, Lisboa
} 
insistiu, em relação à Alemanha, que esta "teve particulares responsabilidades na desintegração da ex-Jugoslávia" e que assumia à época uma "postura militarista de grande potência no quadro da CEE e da NATO ao tentar impor uma intervenção militar que satisfaça o seu apetite por novas zonas de influência". Esta intervenção, através dos Estados Unidos da América, da NATO ou da UEO, estaria "longe de garantir a pacificação da região", agravando a situação e pondo em risco a paz na Europa e no mundo. No plano nacional, o PCP afirmava que seria "indispensável que o Governo português" defendesse junto das "instâncias internacionais a insistência numa solução pacífica negociada para o conflito da Bósnia-Herzegovina”, opondo-se a qualquer intervenção militar estrangeira e participação das forças portuguesas no território. ${ }^{66}$

A 9 de junho de 1993, o Avante! deu a conhecer uma declaração sobre a guerra na Bósnia-Herzegovina, aprovada em reunião conjunta do Comité pela Paz nos Balcãs ${ }^{67}$ e o Conselho Português para a Paz e Cooperação ${ }^{68}$, alertando que "acrescentar guerra à guerra nunca conduziu à paz. Só a persistência na negociação pode levar à solução do conflito na Bósnia-Herzegovina" ${ }^{69}$

Em agosto, o Avante! denunciava que "pela primeira vez desde a sua criação, em 1949", a NATO preparava-se para intervir diretamente num conflito em plena Europa. O alvo são "as forças sérvias da Bósnia, e o pretexto, como de costume, é a ajuda «humanitária» à população civil" ${ }^{\circ 0}$, e também destaca as negociações em Genebra para a paz na Bósnia-Herzegovina, onde "o porta-voz da Conferência da Paz, John Mills, considera que, com os progressos alcançados, se criou «uma verdadeira atmosfera de confiança para o futuro das negociações»" ${ }^{71}$

Com exceção de uma notícia ${ }^{72}$, relacionada com a dissolução do Parlamento da Sérvia em outubro de 1993, não se verificaram referências ao conflito na imprensa partidária entre agosto de 1993 e os inícios de 1994.

66 "Declaração sobre a guerra da Bósnia-Herzegovina", in Avante!, 9/06/1993, Lisboa

${ }^{67}$ O Comité pela Paz nos Balcãs foi fundado em 1993. Para mais informações ver The Centre For Peace in the Balkans. Contacts \& Links. Consultado a 17/06/2012. in <http://www. balkanpeace.org/index.php?index=/content/links.incl>

${ }^{68}$ O Conselho Português para a Paz e Cooperação (CPPC) foi constituído a 24 de Abril de 1976, tendo como objetivo contribuir para a defesa da paz, da segurança e da cooperação a nível internacional e tendo como referência a Carta das Nações Unidas. Para mais informações ver O Blog da Paz. Conselho Português para a Paz e Cooperação. Consultado a 17/06/2012. in $<$ http://cppc.blogs.sapo.pt/400.html>

${ }^{69}$ Ibid

70 "Sérvios na mira dos EUA", in Avante!, 12/08/1993, Lisboa

71 "Recomeço das negociações em Genebra", in Avante!, 19/08/1993, Lisboa

72 "Milosevic dissolve Parlamento", in Acção Socialista, 28/10/1993, Lisboa 
Apesar de no ano de 1994 não se registarem quaisquer intervenções parlamentares relativamente ao conflito na Bósnia-Herzegovina, na imprensa partidária, mais concretamente no Avante!, são publicadas, a 3 de fevereiro, passagens da intervenção feita em Estrasburgo pelo deputado comunista Miguel Urbano Rodrigues na abertura do debate no Parlamento Europeu sobre a situação na ex-Jugoslávia. Contrariamente à intervenção parlamentar do deputado socialista Alberto Martins, proferidas sensivelmente um ano antes, Miguel Urbano Rodrigues considera que os povos envolvidos "foram divididos em bons e maus, em inocentes e agressores. Aos sérvios foi atribuído o papel de maus." Também em relação à proposta de voto de denúncia, aprovado um ano antes embora com a abstenção do PCP, Miguel Urbano Rodrigues considerava ser "há muito evidente que não é possível estabelecer com honestidade uma hierarquia dos crimes cometidos por muçulmanos, croatas e sérvios." Critica, também, o Secretário de Estado dos Estados Unidos da América Warren Christopher, quando este afirma que "não se trata de fazer pressão sobre os muçulmanos; é sobre os sérvios que ela deve ser exercida." 73 Terminou a sua intervenção sublinhando que a pior alternativa era a guerra.

Uma semana depois, o Secretariado do Comité Central do PCP divulgou uma nota sobre a ameaça da intervenção da NATO na Bósnia-Herzegovina, tendo em consideração a culpabilização sérvia por parte da NATO, após o ataque no mercado em Sarajevo, sobre o qual os observadores da ONU não detinham informações sobre a sua origem, pretendendo "tratar em pé de igualdade sérvios, croatas e muçulmanos da Bósnia, ajudando a criar o clima para que ponham fim à guerra civil e cheguem a acordo equitativo por via da negociação pacífica." Esta nota menciona que "tais acordos saíram afinal gorados porque a parte muçulmana pôs em causa o resultado laboriosamente construído, elevando sempre as suas reivindicações. Tal atitude não se pode desligar da ajuda e incentivo dos Estados Unidos da América, que assumem graves responsabilidades pelo prosseguimento da tragédia bósnia, tal como a Alemanha teve no despoletar do processo de desmantelamento da ex-Jugoslávia.

O PCP, que, desde o início do conflito, sempre elevou a sua voz contra uma intervenção militar envolvendo a $\mathrm{CE}$, a ONU ou a NATO, voltou a reclamar do Governo português o empenho no prosseguimento dos esforços de negociação e ajuda humanitária, "actuando por igual junto de todas as partes para a cessação dos combates em toda a Bósnia." 74

\footnotetext{
${ }^{73}$ Miguel Urbano Rodrigues, “A pior alternativa é a guerra”, in Avante! , 3/02/1994, Lisboa

74 “A ameaça de intervenção da NATO na Bósnia”, Avante!, 17/02/1994, Lisboa
} 
Por seu turno, a Acção Socialista, em dois artigos publicados no mês de fevereiro, considerava que "cresce na Europa e no mundo a pressão no sentido de uma intervenção militar que ponha fim à crise na ex-Jugoslávia"75, embora acreditasse que a NATO "não deverá ter necessidade de efectuar ataques aéreos na Bósnia." 76 Ao contrário do que se julgava em fevereiro, tais ataques ocorreram, tendo sido documentados pelo Avante!. ${ }^{77}$

A 19 de maio, o Avante! noticia que "o levantamento de sanções internacionais contra a Jugoslávia constituiria «um poderoso estimulante» do processo de paz na Bósnia segundo Slobodan Milošević"78, tendo-se seguido um período de tréguas ${ }^{79}$ que seria terminado após a votação esmagadora dos sérvios da Bósnia contra o plano de paz internacional na Bósnia-Herzegovina no referendo organizado em agosto.$^{80} \mathrm{Na}$ sequência deste resultado, surgiram propostas de resolução do conflito, que sempre redundavam, segundo o PCP, "em detrimento do povo sérvio". Mas, em setembro, o Avante! avança que, finalmente, a CE mostrava interesse em alcançar a paz na região ${ }^{81}$, enquanto os Estados Unidos da América pediam ao Conselho de Segurança da ONU “o levantamento do embargo de armas - em vigor para toda a ex-Jugoslávia - a favor do governo bósnio." ${ }^{82}$

Com efeito, a 10 de dezembro de 1994, a Assembleia da República recebe a "Declaração sobre a ex-Jugoslávia" 83 , onde é analisada a degradação das agressões; a "purificação étnica" e a violação dos Direitos do Homem, reafirmando que todas as resoluções do Conselho de Segurança das Nações Unidas relativamente a esta questão deveriam ser consideradas e respeitadas.

Quatro dias depois, o cessar-fogo assinado pelos líderes políticos dos sérvios e dos muçulmanos foi quebrado, segundo o PS, pelo Presidente Alija Izetbegović, que declarou que "as tropas governamentais maioritariamente muçulmanas não respeitariam o cessar-fogo enquanto os combates não cessassem" ${ }^{\prime 4}$

\footnotetext{
75 “Guerra na Jugoslávia”, in Acção Socialista, 10/02/1994, Lisboa

76 "Guerra na Jugoslávia”, in Acção Socialista, 23/02/1994, Lisboa

77 "Nato intervém na Bósnia", in Avante!, 3/03/1994, Lisboa

78 “Guerra e recusa do diálogo", in Avante!, 19/05/1994, Lisboa

79 "Bósnia", in Avante!, 14/07/1994, Lisboa

80 "Bósnia", in Avante!, 1/09/1994, Lisboa

81 "A proposta de paz é uma solução imperfeita mas positiva", in Avante!, 15/09/1994, Lisboa

82 "Bósnia", in Avante!, 17/11/1994, Lisboa

${ }^{83}$ Não foi possível aceder ao remetente do documento acima referido. "Declaração sobre a ex-Jugoslávia” à Assembleia da República, 10/12/1994, in Arquivo Histórico Parlamentar.

84 "1994-o ano de todas as incógnitas", in Acção Socialista, 29/12/1994, Lisboa
} 
O Secretariado do Comité Central do PCP divulgou uma nota sobre o envolvimento de Portugal no conflito da Bósnia-Herzegovina, em que refere a "participação de forças militares portuguesas numa força da NATO, um facto de que a Comissão de Defesa da Assembleia da República foi informada, sem que, entretanto, tivesse tomado conhecimento «da natureza da operação, nem do estatuto jurídico atribuído às forças portuguesas nem dos efectivos portugueses a ela atribuído.»" ${ }^{85} \mathrm{O}$ PCP aproveitou para exigir que o Governo esclarecesse de imediato o país acerca do conteúdo total da operação e sobre os eventuais compromissos assumidos.

\subsection{Quinto momento - O Acordo de Supressão de Vistos entre Portugal e a Croácia}

"Onze anos após a morte do ditador Tito, em 1991, a guerra civil instalou-se na Croácia, alastrando no ano seguinte para a Bósnia-Herzegovina". ${ }^{86}$

É com base nesta contextualização histórica relativa à guerra da Croácia, que o discurso de Martins Goulart ${ }^{87}$, deputado do Partido Socialista, se inseriu. De facto, a guerra na Bósnia-Herzegovina atingiu o seu clímax no ano de 1995 , tendo ocupado a atenção dos partidos políticos com assento parlamentar. Na sua intervenção referiu os mais de 150000 mortos e desaparecidos bem como os 2 milhões de desalojados na região.

O deputado socialista interveio em plenário com o objetivo de promover o debate quanto à definição de uma política comum de vistos da União Europeia relativamente a países terceiros, tendo sido deliberado pela Assembleia da República "por maioria qualificada, sob proposta da Comissão e após consulta do Parlamento Europeu, adoptar as medidas conducentes à criação de um modelo único de visto como condição necessária para a realização do mercado interno e a concretização da livre circulação das pessoas". ${ }^{88}$

85 "Bósnia", in Avante!, 5/01/1995, Lisboa

${ }^{86}$ Martins Goulart, Aprovação para ratificação do acordo por troca de notas sobre supressão de vistos entre o governo entre o governo da República Portuguesa e o Governo da República da Croácia. 19 de janeiro de 1995 in <http://www.parlamento.pt/Intervencoes/Paginas/DetalheIntervencao.aspx?BID=41009>. (Consultado entre março e dezembro de 2011).

${ }^{87}$ Para aceder à biografia de Martins Goulart, ver informação disponível em Assembleia da República. Martins Goulart. Consultado a 21/10/2011. in <http://www.parlamento.pt/DeputadoGP/Paginas/Biografia.aspx?BID=182>

${ }^{88}$ Martins Goulart, Aprovação para ratificação do acordo por troca de notas sobre supressão de vistos entre o governo entre o governo da República Portuguesa e o Governo da República da 
Referiu, ainda, a importância do Relatório Lehne, que "alerta, com ênfase, para o facto de que permanece ainda em situação de impasse a resolução de algumas questões essenciais, como das medidas relativas à definição de uma lista de países terceiros cujos cidadãos necessitam de vistos para entrar nas fronteiras externas da União, ou a harmonização dos controlos das pessoas nessas fronteiras externas." Este mesmo relatório foi defendido por José Barros Moura, deputado do Parlamento Europeu, eleito pelo PS nas eleições para esta instituição em 1994, que se manifestou a favor da "viabilização de uma política comum de vistos", no intuito de garantir a livre circulação na União Europeia, assegurando, simultaneamente, a segurança dos cidadãos, por um lado, e garantindo a não discriminação de cidadãos oriundos de países terceiros, por outro. O objetivo seria evitar a proliferação da ideia de uma "Europa securitária e fechada ao exterior". ${ }^{89}$ Tornava-se, deste modo, importante proceder à elaboração de uma proposta de resolução com vista à aprovação de tal acordo.

Em relação ao Partido Comunista Português, através da intervenção em plenário do deputado António Filipe ${ }^{90}$, não se opôs ao acordo de supressão de vistos entre Portugal e a Croácia. De facto, o PCP tinha adotado a mesma posição relativamente ao caso da Eslovénia a 9 de setembro de $1994 .^{91}$

O objetivo seria, portanto, ter conhecimento do que o Governo "pensa sobre o relacionamento do Estado português com outros Estados do mundo", por um lado, e, por outro, saber se efetivamente existia uma política de supressão de vistos ou se tal "política é apenas ditada por compromissos assumidos,

Croácia. 19 de janeiro de 1995 in <http://www.parlamento.pt/Intervencoes/Paginas/DetalheIntervencao.aspx ?BID=41009>. (Consultado entre março e dezembro de 2011).

${ }^{89}$ José Barros Moura, cit. in Martins goulart, Aprovação para ratificação do acordo por troca de notas sobre supressão de vistos entre o governo entre o governo da República Portuguesa e o Governo da República da Croácia. 19 de janeiro de 1995 in <http://www.parlamento. $\mathrm{pt} /$ Intervencoes/Paginas/DetalheIntervencao.aspx $\mathrm{BID}=41009>$. (Consultado entre março e dezembro de 2011).

${ }^{90}$ Para aceder à biografia de António Filipe, ver informação disponível em Assembleia da República. António Filipe. Consultado entre março e dezembro de 2011. in <http://www.parlamento.pt/DeputadoGP/Paginas/Biografia.aspx?BID=209>

${ }^{91}$ António filipe, Aprovação para ratificação do acordo por troca de notas sobre supressão de vistos entre o governo entre o governo da República Portuguesa e o Governo da República da Croácia. 19 de janeiro de 1995 in <http://app.parlamento.pt/DARPages/DAR_ FS .aspx?Tipo $=\mathrm{DAR}+\mathrm{I}+\mathrm{s} \% \mathrm{C} 3 \%$ A 9 rie $\&$ tp $=\mathrm{D} \&$ Numero $=33 \&$ Legislatura $=\mathrm{VI} \&$ SessaoLegislativa $=4 \&$ Data $=1995-01-20 \&$ Paginas $=1217-1217 \&$ PagIni $=0 \&$ PagFim $=0 \&$ Observacoes $=\&$ Suplement $\mathrm{o}=. \&$ PagActual $=0 \&$ pagFinalDiarioSupl $=\& i d p a g=\& i d i n t=41011 \&$ idact $=\& i d d e b=>$. Consultado entre março e dezembro de 2011) 
designadamente a nível dos acordos de Schengen, sem que Portugal tenha, afinal, uma palavra autónoma a dizer". ${ }^{2}$

Luís Sousa de Macedo, Secretário de Estado das Comunidades Portuguesas, interveio em plenário, em resposta ao deputado António Filipe, com o objetivo de explicar as motivações relativas à decisão de Portugal de concluir um acordo de supressão de vistos entre o Governo da República Portuguesa e o Governo da República da Croácia.

De facto, Portugal havia, em 1994, tomado a decisão em denunciar o acordo de supressão de vistos que vigorava até então com a Jugoslávia desde 1975, ainda sob a chefia do Marechal Tito. Assim, os cidadãos dos novos Estados resultantes do desmembramento da Federação jugoslava teriam que ficar sujeitos à necessidade de visto, dando relevância ao caso da Croácia. No entanto, e tendo em consideração que as autoridades croatas haviam optado pela prática de uma política baseada na isenção de vistos a cidadãos nacionais, houve a necessidade de proceder à conclusão de um acordo bilateral entre a República Portuguesa e a República da Croácia. O acordo seguia, assim, as linhas orientadoras de um outro acordo de supressão de vistos com a Eslovénia, tendo como principais objetivos "a harmonização da política nacional em matéria de vistos e de circulação de pessoas na Europa, a que Portugal se comprometeu, nomeadamente, pela adesão, em junho de 1991, ao Acordo Schengen" ${ }^{93}$ Além disso, são destacadas as políticas de segurança e de imigração, considerando que "não se prevê que os cidadãos desta República possam vir a colocar problemas ao nosso país por forma a pôr em risco a segurança nacional, nem se prevê um afluxo desmesurado de cidadãos daquela República a Portugal". ${ }^{4}$

Foi submetida à aprovação da Assembleia da República e ratificação, o Acordo por Troca de Notas sobre Supressão de Vistos entre o Governo da República Portuguesa e o Governo da República da Croácia, que resultou do diálogo entre os Ministérios dos Negócios Estrangeiros de Portugal e da Croácia, Luís Sousa de Macedo terminou a sua intervenção reforçando a total

${ }^{92}$ Ibid.

${ }^{93}$ Luís Sousa de Macedo, Aprovação para ratificação do acordo por troca de notas sobre supressão de vistos entre o governo entre o governo da República Portuguesa e o Governo da República da Croácia. 19 de janeiro de 1995 in <http://www.parlamento.pt/Intervencoes/Paginas/DetalheIntervencao.aspx?BID=108038>. (Consultado entre março e dezembro de 2011).

${ }^{94}$ Luís Sousa de Macedo, Aprovação para ratificação do acordo por troca de notas sobre supressão de vistos entre o governo entre o governo da República Portuguesa e o Governo da República da Croácia. 19 de janeiro de 1995 in <http://www.parlamento.pt/Intervencoes/Paginas/DetalheIntervencao.aspx?BID=108038> . (Consultado entre março e dezembro de 2011). 
disponibilidade para debater a política de supressão de vistos na Assembleia da República, que pedia o deputado António Filipe. Reforçou, ainda, a possibilidade de adaptar e reformular a política de imigração face às necessidades dos cidadãos do Estado croata.

Manuel Queiró ${ }^{95}$, em representação do CDS-PP, interveio então com o objetivo de informar da aprovação do seu partido, sobre a proposta de resolução relativamente ao Acordo sobre a Supressão de Vistos entre Portugal e a Croácia. No entanto, o deputado do CDS-PP parecia não compreender a natureza do acordo em questão, já que a Eslovénia havia sido utilizada "para justificar este Acordo por parte de Portugal"96.

Segundo Manuel Queiró, a Croácia estava envolvida, direta ou indiretamente, no conflito da Bósnia-Herzegovina, havendo, portanto, cidadãos bósnios que "são ou tendem a ser, ao mesmo tempo, nacionais da Croácia", e a "política oficial, ou oficiosa, da República da Croácia coloca a possibilidade de esse conflito originar movimentos migratórios" 97 A preocupação residia, assim, no fluxo considerável de migrantes que tal acordo poderia originar. $\mathrm{O}$ objetivo seria perceber se o Governo havia refletido e/ou debatido sobre tal situação e que medidas e reservas se propunha apresentar, pelo que os cidadãos de origem croata e/ou bósnios croatas poderiam facilmente entrar em território português, tendo que apresentar um único documento: o passaporte. Ainda que os cidadãos portugueses não tivessem a obrigatoriedade de apresentar vistos aquando da entrada na Croácia - decisão unilateral por parte do Governo da Croácia - e o Estado português tivesse demonstrado a sua aprovação neste âmbito, através da assinatura de acordos, quer europeus, quer internacionais, um debate e reflexão deveriam ser promovidos no seio do Parlamento relativamente à política de supressão de vistos em Portugal, para cidadãos europeus e lusófonos.

O deputado tinha como objetivo impedir o avanço de uma política de supressão de vistos entre Portugal e Croácia de forma "absolutamente casuística", procurando afirmar a soberania portuguesa, conforme se poderia ler no Programa Eleitoral e de Governo do Partido do Centro Democrático Social

${ }^{95}$ Para aceder à biografia de Manuel Queiró, ver informação disponível em Assembleia Da República. Manuel Queiró. Consultado entre março e dezembro de 2011. in <http://www. parlamento.pt/DeputadoGP/Paginas/Biografia.aspx?BID=228>.

${ }^{96}$ Manuel Queiró, Aprovação para ratificação do acordo por troca de notas sobre supressão de vistos entre o governo entre o governo da República Portuguesa e o Governo da República da Croácia. 19 de janeiro de 1995 in <http://www.parlamento.pt/Intervencoes/Paginas/DetalheIntervencao.aspx? $\mathrm{BID}=41008>$. (Consultado entre março e dezembro de 2011).

${ }^{97}$ Ibid 
- Partido Popular, em 1995, onde uma das prioridades consistia na afirmação da soberania de Portugal, tendo em consideração uma "crescente usurpação de poderes e competências de soberania pela burocracia europeia. A vida portuguesa é cada vez mais regulamentada por actos comunitários que os órgãos de soberania não discutem e os portugueses não conhecem" (PARTIDO DO CENTRO DEMOCRÁTICO SOCIAL - PARTIDO POPULAR, 1995:16).

\subsection{Sexto momento - Com as eleições legislativas de 1995 no horizonte}

Em junho de 1995, o Gabinete de Imprensa do PCP, divulgou uma nota sobre a evolução da situação na Bósnia-Herzegovina, onde demonstrava profunda inquietação pela persistência das grandes potências em "[tentar] impor pela força das armas soluções unilaterais que ignoram os ensinamentos da história e o complexo mosaico de factores de carácter social, étnico e religioso na região balcânica, está a provocar uma nova escalada do conflito e a alimentar, em todas as partes, o crescimento de forças nacionalistas obscurantistas e fascizantes que em nada se identificam com os reais interesses dos povos". O PCP salientava que "só pela via do diálogo e da negociação política seria possível encontrar uma solução justa e duradoura para os problemas da região, nomeadamente através da preparação e convocação de uma conferência internacional com a adequada composição, incluindo as partes em conflito." Com esta nota, o PCP volta a mencionar o "injusto bloqueio à nova Jugoslávia bem como condena e exige o fim das raides da NATO, opondo-se ao envolvimento militar de Portugal no conflito." 98

Sobre este tema, o recurso a ações militares na Bósnia-Herzegovina só foi admitido pelo chefe do Governo português "como solução pontual de reforçar o diálogo e não como saída para o problema". 99

Também o PS, através de um artigo na Acção Socialista, considerava que "a via diplomática parece ser a chave neste momento ao alcance da União Europeia para libertar os seus militares reféns (ONU), humilhados nas mãos dos sérvios da Bósnia"100.

A 8 de agosto, a Embaixada da Bósnia-Herzegovina, a pedido do Ministério dos Negócios Estrangeiros bósnio, enviou uma nota verbal à Embaixada de Portugal em Madrid pedindo para que fosse discutido o genocídio naquele

\footnotetext{
98 “A aposta na ameaça militar”, in Avante!, 14/06/1995, Lisboa

${ }^{99}$ Cavaco Silva cit. in "Portugal defende solução política”, in Diário de Notícias, 30/05/1995, Lisboa

100 “Guerra na Jugoslávia”, in Acção Socialista, 1/06/1995, Lisboa
} 
país. ${ }^{101}$ Durante os meses de julho e agosto, o jornal Avante! foi divulgando notícias sobre a evolução do conflito.

Setembro marcou o reconhecimento, por parte da República Federal da Jugoslávia, da "existência da Bósnia-Herzegovina e esta, por seu turno aceitou uma «República Sérvia» no seu território." 102 Com este acordo, segundo a notícia do órgão oficial do PS, as tropas croatas e muçulmanas desencadearam uma ofensiva contra posições sérvias "a fim de aumentarem as suas zonas de influência"103

O Avante!, por seu lado, preferia enfatizar as palavras de Oliver Potezica, do Partido Socialista da Sérvia, que considerava quer no processo negocial, quer no delinear de alternativas de paz, as grandes potências desempenharam um "papel muito negativo", referindo a "«necessidade de novos acordos, novas formas de integração», alertando para a ameaça que pode representar para a nossa civilização a «instrumentalização de conflitos étnicos e confessionais»" 104

A crítica subiu de tom com um artigo de Carlos Aboim Inglez publicado três dias antes das eleições legislativas em Portugal, classificando esta "paz injusta e insegura" como "uma derrota da Europa e da ONU", refletindo "a matização [SIC] e americanização do conflito bósnio" impondo na Europa, a sua «nova ordem»."105

12 de outubro foi dia que marcou a celebração do acordo que estabeleceu a estrutura político-institucional da Bósnia-Herzegovina, e reconheceu a existência de duas entidades: a Federação Croato-Muçulmana e a República Sérvia da Bósnia-Herzegovina. A guerra na Bósnia ocupou um espaço considerável na rubrica "Internacional" do jornal Acção Socialista, sendo a partir de então mais frequente a referência ao conflito. Foi, sem dúvida, um ano-chave, não apenas para o fim da guerra na Bósnia-Herzegovina, mas também para o Partido Socialista, pois conseguiu constituir governo, encabeçado por António Guterres, saiu vencedor nas eleições de 1 de outubro, sucedendo, deste modo, a Cavaco Silva.

A 28 de novembro, o Diário de Notícias sintetizou a posição dos diferentes partidos políticos relativamente à intervenção militar portuguesa na Bósnia-Herzegovina. Azevedo Soares, do PSD, considerou que "não podemos esquecer que pertencemos à NATO e que nessa medida temos obrigações, já

${ }^{101}$ Embaixada da Bósnia-Herzegovina em Madrid à [Embaixada de Portugal em Madrid], 8/08/1995, in Arquivo Histórico Parlamentar

102 “Guerra na Jugoslávia, in Acção Socialista, 14/09/1995, Lisboa

103 "Guerra na Jugoslávia”, in Acção Socialista, 21/09/1995, Lisboa

104 "Debates no espaço internacional"; in Avante!, 7/09/1995, Lisboa

${ }^{105}$ Carlos Aboim Inglez, "Bósnia - a reviravolta”, in Avante!, 28/09/1995, Lisboa 
que temos também direitos" 106 bem como Jorge Ferreira, do PS, lembrou que "devemos honrar os nossos compromissos", colocando duas condições: "que sejam tropas profissionais e que o contingente seja à medida de Portugal"107, enquanto que o CDS-PP exigia a presença do novo líder do PSD, Fernando Nogueira, numa reunião na Assembleia da República pedida pelo Governo, "para explicar os compromissos que terá assinado enquanto ministro da Defesa" 108 no governo de Cavaco Silva. Como vozes discordantes encontram-se Luís Sá, deputado do PCP, que condenava esta "missão militar não humanitária da NATO, e não da ONU ou da Organização de Segurança e de Cooperação Europeia" 109 , bem como Isabel de Castro, deputada do PEV, que duvida dos resultados que possam ser obtidos através desta intervenção militar.

Rui Fernandes, no Avante!, escreveu um apontamento sobre Portugal, a NATO e a Bósnia-Herzegovina, realçando a posição do PCP relativamente ao envolvimento das Forças Armadas Portuguesas em ações militares fora do território nacional. ${ }^{110}$ Uma semana depois, este jornal noticiava os acordos de Dayton, classificando-os como sendo "pretensões de Washington em impor os seus interesses e as suas «soluções» um pouco por todo o mundo". ${ }^{111}$

Noutra perspetiva, a Acção Socialista considerava Dayton como a "paz possível"112, realçando que as sanções contra a República da Jugoslávia haviam sido levantadas, bem como o destacamento de tropas da NATO, nas quais estaria confirmada a participação de tropas portuguesas, "para garantir o respeito pelo acordo de Dayton e preparar o sistema de acantonamento de tropas e desarmamento das forças em confronto: sérvios, croatas e bósnios", considerando como "um processo que o Governo conduziu de forma muito clara" 113 , de modo a que Portugal fizesse parte da "maior operação militar da história da NATO". ${ }^{114}$ Apesar de o Governo PS se congratular da missão, o

${ }^{106}$ Azevedo Soares, cit. in Eduardo Mascarenhas, "Brigada agasalha-se", in Diário de Notícias, 28/11/1995, Lisboa

107 Jorge Ferreira, cit. in Eduardo Mascarenhas, "Brigada agasalha-se”, in Diário de Notícias, 28/11/1995, Lisboa

${ }^{108}$ João Pedro Henriques, "PP «entala» Nogueira com Bósnia”, Diário de Notícias, 28/11/1995, Lisboa

${ }^{109}$ Luís Sá, cit in Eduardo Mascarenhas, "Brigada agasalha-se”, in Diário de Notícias, 28/11/1995, Lisboa

${ }^{110}$ Rui Sá Fernandes, "Um apontamento sobre Portugal, a NATO e a Bósnia”, in Avante!, 23/11/1995, Lisboa

111 "Os acordos de Dayton", in Avante!, 30/11/1995, Lisboa

112 “Acordo de Dayton - a paz possível”, in Acção Socialista, 30/11/1995, Lisboa

113 "Envio de tropas para a Bósnia", in Acção Socialista, 7/12/1995, Lisboa

114 “Guerra na Bósnia”, in Acção Socialista, 21/12/1995, Lisboa 
PCP ironizou na última edição de 1995 do Avante!: "a ONU entregou ontem o comando à NATO na Bósnia." 115

Tanto Mário Soares, então Presidente da República Portuguesa, como António Guterres, Primeiro-ministro de Portugal, procuraram discutir o envio de militares para a Bósnia. Na reunião do Conselho Superior de Defesa onde havia sido aprovada a integração do BAI ${ }^{116}$ na força da NATO na Bósnia", Mário Soares sublinhou o "dever de solidariedade" subjacente à missão. ${ }^{117}$

O Presidente da República justificava o apoio ao envio de tropas de combate para a força da NATO, a partir de janeiro de 1996, na Bósnia, considerando ser Portugal "uma Nação consciente e membro da NATO, apesar da existência de riscos". ${ }^{118}$

\subsection{Reflexões sobre a documentação analisada}

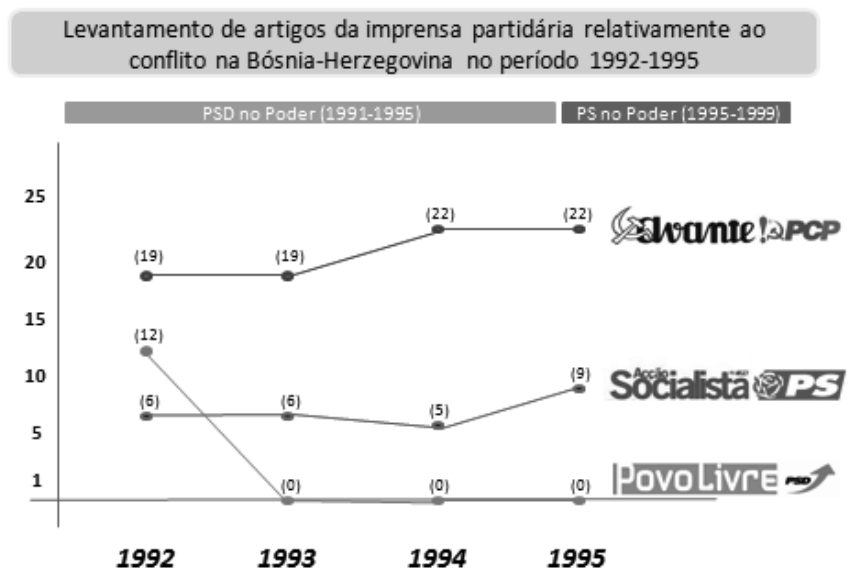

Figura 2 - Levantamento de artigos da imprensa partidária relativamente ao conflito na Bósnia-Herzegovina no período 1992-1995 (esquema realizado pela autora)

115 "Bósnia", in Avante!, 21/12/1995, Lisboa

${ }^{116} \mathrm{O}$ batalhão da BAI (Brigada Aerotransportada Independente) ficou na zona de Mostar, sob comando francês. A força da NATO na Bósnia contou com cerca de mil homens da BAI in Octávio de Cerqueira Rocha, "Portugal e as Operações de Paz na Bósnia - A Preparação das Forças". Nação e Defesa. Portugal e as Operações de Paz na Bósnia. Instituto de Defesa Nacional. N. ${ }^{\circ}$ 92, 2. ${ }^{a}$ série. 2000. Lisboa. pp. 71-92. in <http://www.idn.gov.pt/publicacoes/nacaodefesa/ textointegral/NeD92.pdf>. (Consultado entre março e dezembro de 2011).

${ }^{117}$ Mário Soares, cit. in Eduardo Mascarenhas, "Para a Bósnia em força", in Diário de Notícias, 1/12/1995, Lisboa

${ }^{118}$ Eduardo Mascarenhas, “A consciência da Nação”, in Diário de Notícias, 2/12/1995, Lisboa 


\subsubsection{Partido Social Democrata}

Em grande parte do período analisado, o PSD constituía a força política com maior representação parlamentar, fruto de uma maioria absoluta na Assembleia da República. A posição do PSD caraterizou-se por uma postura alinhada com a defesa das decisões europeias, tanto no que respeita ao reconhecimento das independências das antigas repúblicas jugoslavas, como no que toca à intervenção militar (portuguesa), apoiando sempre, a participação nacional, através das forças militares internacionais da NATO ou da ONU.

De salientar que o PSD, através de Leonor Beleza, foi o primeiro partido a levar à Assembleia da República um voto de denúncia relativamente às violações dos direitos humanos na Bósnia-Herzegovina contra mulheres e crianças muçulmanas.

O PSD, no que respeita a supressão de vistos, adotou uma postura flexível, mostrando-se disponível para debater a política de imigração respeitante aos países da ex-Jugoslávia.

Apesar de ter perdido as eleições legislativas de outubro de 1995 e ter deixado de ser governo, mesmo na oposição, o PSD manteve a sua opinião relativamente à participação militar portuguesa nas forças da NATO na Bósnia-Herzegovina.

Como é possível analisar pela frequência de artigos no Povo Livre, esta temática foi, sobretudo, alvo de referência durante o primeiro semestre de 1992, aquando da Presidência Portuguesa das Comunidades Europeias. Contrariamente ao que seria expetável, o jornal Povo Livre parece não ter refletido o espírito de dedicação dos parlamentares para com esta causa. Entre 5 de fevereiro de 1992 e 20 de dezembro de 1995, podem ser encontrados apenas 12 artigos referentes à situação na ex-Jugoslávia, sendo que estas referências devem ser observadas e comentadas no âmbito da Presidência Portuguesa das Comunidades Europeias, podendo depreender-se, portanto, uma preocupação por parte dos sociais-democratas em transmitir a imagem de um país pronto para contribuir internacionalmente para uma solução política nos Balcãs.

\subsubsection{Partido Socialista}

Comparativamente aos sociais-democratas, os parlamentares socialistas foram mostrando-se um pouco tímidos no que diz respeito à intervenção em plenário face à questão jugoslava, sendo denotada porém, por parte destes, a identificação dos sérvios como os culpados do conflito e Josip Broz Tito como um ditador. 
De referir que no congresso do PS de 1992, apenas no relatório do Secretário-Geral, que consiste numa súmula da atividade partidária durante os dois anos anteriores, se encontra um pequeno capítulo sobre a posição do PS relativamente a assuntos externos. No entanto, o referido relatório do Secretário-Geral não contempla a questão da Bósnia-Herzegovina.

Durante o conflito, o PS apoiou as iniciativas da NATO e das Comunidades Europeias, alinhando junto do PSD com as medidas tomadas. Este alinhamento faz-se notar, por exemplo, na proposta de voto de denúncia por parte do PSD, bem como nas intervenções de parlamentares socialistas no Parlamento Europeu, apesar dos esforços do PCP em tentar que o PS, à época, na oposição, assumisse uma posição contrária à do Governo. De igual modo, no que toca à supressão de vistos, o PS mostrou-se alinhado com o PSD e com as diretrizes europeias.

Relativamente à imprensa partidária socialista, os artigos publicados serviram, sobretudo, de acompanhamento do conflito, defendendo a posição europeia e criticando os sérvios pela escalada do conflito. De referir que à medida que as eleições legislativas de 1995 se aproximavam, e sendo cada vez mais certa a sua responsabilidade governativa daí em diante, também a Acção Socialista foi acompanhando com mais enfoque, sobretudo, as ações futuras a tomar na resolução do mesmo bem como a posição portuguesa e a intervenção militar na resolução do conflito, o que sucedeu, já estando no poder.

\subsubsection{Partido Comunista Português}

O PCP evidencia-se, claramente, tanto na abordagem, como no tratamento e tomada de posição relativamente à questão jugoslava.

Desde o início, o PCP, mostrou-se contra as intervenções militares na região, bem como defendeu a não culpabilização de um líder/grupo específico como é notório pelas propostas de alteração votadas em plenário da Assembleia da República, abstiveram-se, embora defendendo a preservação dos Direitos Humanos. No entanto, mesmo neste esforço de congregar unanimidade à esquerda, nem sempre tal aconteceu, como foi notório na votação de denúncia relativamente às violações dos Direitos Humanos na ex-Jugoslávia, documento que o PEV aprovou.

As críticas ao PS e ao PSD vão subindo de tom à medida que estes partidos vão defendendo as posições tomadas pelas «grandes potências mundiais»e, numa segunda fase, levadas a cabo por organizações internacionais como a NATO. 
O PCP apela ao diálogo tripartido como forma de negociar a resolução do conflito. De certo modo, e como é possível verificar pelas várias notas emitidas pelo partido, divulgadas através do seu jornal Avante!, tentou formar a opinião à esquerda, em contraponto com o PS e o PSD. Estas notas criticavam, sobretudo, o que consideravam ser uma culpabilização sérvia por parte da comunidade internacional, não alinhando, por exemplo, na aplicação de embargos à ex-Jugoslávia, bem como dando conta da desconstrução de algumas notícias que revelavam também a responsabilidade de outras partes envolvidas, nomeadamente os bósnios muçulmanos.

O PCP foi parte ativa no debate político, sendo frequente o pedido de esclarecimentos ao governo, sobre a posição portuguesa relativamente ao conflito e, especificamente, no que respeita à intervenção militar portuguesa.

De facto, ao longo do conflito, o PCP desdobrou-se em múltiplas intervenções no Avante! relativas à situação na Bósnia, procurando expressar a sua preocupação sobre o destino do povo jugoslavo naquele momento e no futuro, tanto a nível regional, como a nível internacional. Os refugiados jugoslavos, o alerta contra o racismo, as ameaças de uma intervenção militar ocuparam, deste modo, inúmeras páginas do Avante!, bem como dezenas de fotos captadas, quer por correspondentes, quer via imprensa internacional, ou ainda cartoons com o objetivo de caricaturar determinadas personalidades da política internacional. Evidencia-se, a 25 de fevereiro de 1993, uma secção dedicada inteiramente à Jugoslávia, mais precisamente à sua história, comentando o presente e perspetivando o futuro nos Balcãs.

Mesmo após o fim do conflito, o PCP permaneceu claramente interessado na região da ex-Jugoslávia, intervindo através de declarações, comunicados e notas de imprensa, sobretudo, aquando da morte do líder sérvio, Slobodan Milošević, a 11 de março de 2006, podendo ler-se o seguinte: "O falecimento de Milošević contribuirá para que perdure o conjunto de mentiras e falsificações históricas que deram suporte à ilegítima guerra de agressão, movida pelos Estados Unidos e pela NATO na base dos mais diversos pretextos, ao processo de sequestro e entrega de Milošević ao Tribunal de Haia, ao desmembramento violento do Estado Jugoslavo e à criação de uma nova situação geopolítica que visou, no essencial, a criação de um conjunto de novos países e protectorados subordinados à estratégia e objectivos de dominação dos Estados Unidos e dos seus aliados naquela região." 119

${ }^{119}$ Anabela Fino, "Slobodan A morte matada de Slobodan Milosevic". Avante! (11 de março) 2006. in <http://www.avante.pt/pt/1685/internacional/13419/> . (Consultado a 01/04/2011). 


\subsubsection{Partido do Centro Democrático Social - Partido Popular}

Relativamente ao CDS-PP verifica-se uma participação menor no debate político quanto ao conflito na ex-Jugoslávia, comparativamente aos restantes partidos em análise. De uma forma geral, o CDS-PP manteve uma certa distância e uma atitude pouco interventiva no Parlamento relativamente ao assunto em estudo, procurando intervir apenas em nome e defesa da soberania nacional, como é caraterizado na intervenção de Manuel Queiró relativamente ao acordo sobre a supressão de vistos entre Portugal e a Croácia e ao fluxo migratório de cidadãos oriundos da ex-Jugoslávia. Já em relação ao voto de denúncia proposto pelo PSD, o CDS-PP aprovou-o, sem, no entanto, existir qualquer manifestação pública em plenário, ao contrário dos restantes partidos.

De notar que o CDS-PP, de forma a destacar-se do outro partido à direita o PSD -, desenvolveu uma política baseada, sobretudo, no euroceticismo e na imigração, procurando representar a "direita democrática, popular e nacional" (PARTIDO POPULAR, 1993: 6), já sob a liderança de Manuel Monteiro. ${ }^{120}$

No que respeita à intervenção militar portuguesa, bem como à política externa e defesa, demonstrou ser um apoiante incondicional da NATO, considerando-a "como «fórum» essencial do debate das questões de defesa e segurança colectiva." (PARTIDO POPULAR, 1991:2)

Dada a inexistência de um jornal do partido, o número de intervenções por parte de parlamentares foi pouco relevante no período em análise, remetendo para as organizações internacionais a discussão sobre a resolução do conflito, preocupando-se apenas quando o assunto fazia referência a aspetos relativos à manutenção da soberania nacional.

De igual modo, o assunto não foi abordado nem nos programas eleitorais, nem nos congressos realizados pelo CDS-PP entre 1992 e 1995, mais precisamente, o X Congresso (a 20 de março de 1992); o XI Congresso (a 23 de janeiro de 1993); o XII Congresso (a 18 de fevereiro de 1994) e o XIII Congresso (a 11 de fevereiro de 1995).

\section{Conclusões}

Neste capítulo irei fazer uma reflexão sobre o trabalho de investigação realizado, assentando em três pontos de referência. Em primeiro lugar, serão

${ }^{120}$ Manuel Monteiro foi eleito para a presidência do CDS-PP, no X Congresso (20 de março de 1992). 
sugeridos trabalhos futuros, de modo a complementar a investigação já realizada. Em segundo lugar, serão dadas a conhecer algumas considerações sobre o debate político e a posição dos partidos políticos quanto ao conflito na Bósnia-Herzegovina. Em terceiro lugar, discutirei o paradigma do conflito na minha visão pessoal.

No âmbito do debate político relativamente ao conflito na Bósnia-Herzegovina, trabalhos futuros poderão ser realizados. Para esta investigação, e como já foi anteriormente mencionado, foram utilizadas como fontes de referência, as intervenções em plenário, a imprensa partidária, as resoluções dos congressos dos partidos políticos com assento parlamentar, a correspondência diplomática e os jornais Jornal de Notícias e Diário de Notícias.

No entanto, creio que será possível aprofundar este tema através do acesso ao Arquivo Diplomático do Ministério dos Negócios Estrangeiros. Seria também importante proceder à recolha e análise de intervenções no Parlamento Europeu ou das reuniões dos grupos de trabalho da Comissão Parlamentar dos Assuntos Europeus ou da Comissão Parlamentar dos Negócios Estrangeiros, Comunidades Portuguesas e Cooperação. Aproveito para mencionar o facto de, aquando da deslocação a Lisboa para aceder ao Arquivo Histórico Parlamentar, me terem sido facultados apenas os relatórios e a correspondência recebida e/ou expedida da Comissão Parlamentar dos Assuntos Europeus e da Comissão Parlamentar dos Negócios Estrangeiros, das Comunidades Portuguesas e Cooperação.

Alguns jornais de referência como o Público ou o Expresso poderão ser, ainda, utilizados, à semelhança do que foi feito para os jornais acima indicados, focando, eventualmente, os artigos de opinião.

A televisão ou ainda a rádio serão fontes a explorar, tendo em consideração o período 1992-1995, já que foi um conflito mediatizado, havendo a possibilidade de encontrar informações relevantes. Comentários e entrevistas de parlamentares portugueses à televisão portuguesa poderão existir, aquando da Presidência Portuguesa das Comunidades Europeias, relativamente ao conflito. Destaca-se, a este propósito, a vinda dos líderes das partes envolvidas no conflito a Portugal, em 1992.

De notar, ainda, que aquando da partida das tropas portuguesas para a Bósnia-Herzegovina em 1996, uma equipa da rádio da Antena 1 produziu o programa "Bom dia Bósnia" ${ }^{21}$, tendo como objetivo aproximar as famílias

${ }^{121}$ Rui Miguel Tovar, "Bom dia Bósnia. As memórias de uma equipa de rádio com seis avançados". in <http://www.ionline.pt/desporto/bom-dia-bosnia-memorias-uma-equipa-radio-seis-avancados $>$. (Consultado a 21 de maio de 2012). 
dos militares estacionados na região e dar a conhecer o dia-a-dia das tropas portuguesas. Seria, eventualmente, interessante recuperar o conteúdo dessas emissões e analisá-lo à luz do debate político ou da posição do Estado português relativamente ao conflito.

Quanto ao debate político e à posição dos partidos políticos sobre o conflito na ex-Jugoslávia, destaca-se um consenso entre PS e PSD entre 1992 e 1995. De facto, no que diz respeito à política externa o PS e o PSD estiveram alinhados desde 1975. De referir, igualmente, que à época Mário Soares, do Partido Socialista, era o Presidente da República Portuguesa e Cavaco Silva, do Partido Social Democrata, era o Primeiro-ministro. Havia, portanto, a necessidade de encontrar alguma harmonia entre as duas forças políticas, sobretudo, numa fase durante a qual Portugal foi solicitado a chefiar as negociações para a paz do conflito nos Balcãs. Era importante transmitir uma imagem de um país politicamente unido, numa questão tão evidentemente complicada no contexto europeu. Assim, ainda que existam divergências entre os dois partidos a nível interno, no que diz respeito à Europa, à política externa, o PS e o PSD parecem estar em acordo.

Já a posição do CDS-PP não foi uma surpresa, pois sempre foi um partido conservador, preocupado com a realidade e soberania nacionais, segundo o "Programa Eleitoral e de Governo do Partido do Centro Democrático Social - Partido Popular" (1995). Em termos de política externa, o CDS-PP apontava a necessidade em reforçar as relações com países de língua portuguesa e considerava a NATO necessária, constituindo o "fórum" no qual devem ser discutidas todas as questões relativas à segurança e à defesa. (PARTIDO DO CENTRO DEMOCRÁTICO SOCIAL - PARTIDO POPULAR, 1991:2)

Dos quatros partidos com assento parlamentar o PCP foi o partido que mais reagiu relativamente ao conflito na Bósnia-Herzegovina, e o que mais informação produziu neste sentido, desde declarações, notas do Comité Central do partido, artigos de opinião, entre outros. Daí que grande parte das referências utilizadas sejam provenientes do PCP.

De uma maneira geral, os direitos humanos foram, quer nas intervenções parlamentares, quer na imprensa partidária, um tema discutido pelos quatro partidos políticos, destacando-se a deputada Leonor Beleza, do PSD, pela insistência na tomada de posição face às violações contra mulheres e crianças na Bósnia-Herzegovina. Ao longo do conflito, foram enviados à Assembleia da República relatórios e declarações, informando o Governo português sobre a degradação das agressões. A destacar, ainda, o voto n. 63/VI, relativo às condenações das violações dos Direitos Humanos na ex-Jugoslávia, tendo sido elaborado pela Comissão de Assuntos Constitucionais, Direitos, Liberdades e 
Garantias. Este voto procurava denunciar as "deslocações forçadas de populações civis, a prática sistemática de torturas, homicídios e humilhações de toda a ordem." Pela primeira vez no Parlamento, as violações são caracterizadas como arma de guerra, devendo, portanto, ser punidas. No entanto, este voto não contou com a aprovação por parte do PCP, pelo facto de fazer referência aos crimes cometidos contra mulheres e crianças de etnia muçulmana. O PCP solicitava que, independentemente da etnia ou religião, todos os crimes cometidos contra mulheres e crianças fossem julgados.

Naquilo que muitos observadores consideram, é com base na violação dos direitos humanos na ex-Jugoslávia que a ONU e a NATO decidiram intervir na Bósnia-Herzegovina, alegando a necessidade de intervir em nome de uma guerra humanitária ${ }^{122}$, corrompendo, assim, a Carta das Nações Unidas. ${ }^{123}$ Assim, para autores como Johnstone ou Chomsky, todos os acordos que foram planeados, não constituíam mais do que um grande disfarce para que a potência americana pudesse oficialmente dispor de autoridade militar para intervir. ${ }^{124}$ A verdade é que, segundo a investigadora Diane Johnstone ${ }^{125}$, dos objetivos que haviam sido estabelecidos formalmente em Dayton, nem um parece ter sido executado.

Haverá, portanto, alguma ligação de causalidade entre violação dos direitos humanos e direito de ingerência? Poderá um país intervir militarmente, alegando motivos humanitários? Relativamente a este assunto, destaca-se o relatório elaborado, em 1992, pela Carnegie Endowment for International Peace, onde é discutido "a new principle of international relations: the des-

${ }^{122}$ Alex De Waal, e, Rakiya Omaar. “Can Military Intervention Be "Humanitarian”?”. MER 1987 - Humanitariam Intervention and North-South politics in the 1990's. Volume 24. (Março/ Abril) 1994.in <http://www.merip.org/mer/mer187/can-military-intervention-be-humanitarian> (Consultado a 26 de junho de 2012).

${ }^{123}$ Nations Unies. La charte des Nations Unies. Consultado a 20 de maio de 2012. in <http:// www.un.org/fr/documents/charter/index.shtml>

${ }^{124}$ Noam Chomsky, "L'Otan maître du monde". Le Monde Diplomatique. (Maio) 1999. in <http://www.monde-diplomatique.fr/1999/05/CHOMSKY/12019> (Consultado a 01/04/2011).

${ }^{125}$ Diane Johnstone, "Humanitarian war: making the crime fit the punishment". Masters of the Universe: NATO's Balkan Crusade. (abril) 2000. pp. 147-170 in <http://books.google.pt/ books?id=vAx_FCOwcsC\&pg=PA345\&lpg=PA345\&dq=Masters+of+the+Universe:+NATO $\%$ $27 \mathrm{~s}+$ Balkan+Crusade \&source $=$ bl\&ots=V6gLCCRKEw\&sig=4lxpacV7JTMcael9QWiHWFcSq 3o\&hl=pt-PT\&sa=X\&ei=FTHqT76fIsqR0AX95_h7\&redir_esc $=\mathrm{y} \# \mathrm{v}=$ onepage $\& \mathrm{q}=$ Masters $\% 20$ of $\% 20$ the $\% 20$ Universe $\% 3 \mathrm{~A} \% 20$ NATO $\% 27 \mathrm{~s} \% 20$ Balkan $\% 20$ Crusade $\& \mathrm{f}=$ false $>$. (Consultado a 26/06/2012). 
truction or displacement of groups of people within states can justify international intervention". ${ }^{126}$

A este título, o PCP foi o partido que condenou formal e oficialmente a intervenção militar na ex-Jugoslávia, considerando que só através da persistência nas negociações se poderia alcançar a paz.

Já o PSD, o PSD e o CDS-PP afirmavam que Portugal, enquanto membro da NATO, teria de cumprir os seus deveres.

De notar que Portugal havia entrado na Comunidade Europeia apenas em 1986, pela assinatura de Mário Soares, sendo que em 1992 festejou o 6. ${ }^{\circ}$ aniversário de adesão. Foi o último Estado-membro até 1995, juntamente com a Espanha, a aderir ao projeto europeu. Tendo em mente estes factos, dir-se-ia que o governo de Portugal não queria colocar problemas relativamente à questão jugoslava. Como seria de esperar, Portugal adotou uma posição em conformidade com a maioria dos Estados-membros ${ }^{127}$, chefiados pela Alemanha, no que toca ao reconhecimento da independência das repúblicas jugoslavas por exemplo.

A este título, o PCP fez contínuos apelos para que Portugal não se deixasse conduzir pelos países europeus de maior influência, já que tinha discordado da adesão de Portugal à CEE em 1986. Com a queda do Muro de Berlim a 9 de novembro de 1989, e o fim da Guerra Fria, facilitou a ocorrência de novos conflitos em território europeu. O PCP parecia estar, ainda, influenciado por este contexto histórico, já que considerava os americanos os culpados pela escalada do conflito, dos bombardeamentos da NATO e da desintegração da federação jugoslava. Ainda que a um dado momento, os muçulmanos surjam também como os culpados, sobretudo, no atraso das negociações para a paz, os americanos são criticados nas notas emitidas pelo Comité Central do partido, contrariando a tendência internacional, que assentava na incriminação dos sérvios pela "purificação étnica". O PCP considerou que o conflito na Bósnia-Herzegovina foi nada mais, nada menos do que a "natização [SIC] e americanização" de uma "nova ordem" na Europa. ${ }^{128}$

${ }^{126}$ Carnegie Endowment For International Peace. Changing Our Ways: America and the New World. Consultado a 26/06/2012. in <http://www.carnegieendowment.org/1992/07/01/ changing-our-ways-america-and-new-world/1oq7>.

${ }^{127}$ A Grécia não apoiou os bombardeamentos levados a cabo pela NATO na BósniaHerzegovina, embora não vetando a decisão. Ver informações em Daniel L. Bethlehem, e Marc Weller, The Yugoslav Crisis in International Law. Cambridge: Cambridge University Press, 1997.

${ }^{128}$ Carlos Aboim Inglez, "Bósnia - a reviravolta”, in Avante!, 28/09/1995, Lisboa 
Quanto à intervenção militar, Portugal foi solicitado a atuar na Bósnia-Herzegovina, a pedido da NATO, sem qualquer "estratégia intervencionista ou qualquer política de forçar a entrada", como refere Nuno Severiano Teixeira, que acrescenta "o país ganhou com a presença na ex-Jugoslávia, sobretudo, a nível político-diplomático, mas também a nível militar", tornando-se credível perante a comunidade internacional, apesar das críticas que se fizeram ouvir em 1995 por parte do PCP, que se mostrava desfavorável à intervenção militar, afirmando que Portugal deveria centrar-se nas regiões de real interesse: África. Ainda que Portugal não encarasse à época os Balcãs como uma área de interesse estratégico, atualmente, e tendo em consideração que o país é membro da NATO e da União Europeia e possui um estatuto definido, com uma "política externa ativa europeia e atlântica", Portugal possui interesses de ordem estratégica e de segurança. Assim na opinião deste, "os Balcãs são nos dias de hoje uma área de interesse para Portugal". ${ }^{129}$ Nesta matéria pode afirmar-se que houve um consenso político-partidário entre o PS e o PSD, convergindo na opinião de que a participação portuguesa na NATO confere positivamente ao país direitos, e como contrapartida, também obrigações subjacentes à adesão a esta organização internacional. ${ }^{130}$ Tal como estes dois partidos, a posição do CDS-PP consistia no apoio da intervenção militar portuguesa nas forças da NATO na Bósnia-Herzegovina.

A intervenção militar portuguesa foi, igualmente, apoiada pela opinião pública ao longo dos anos 90, com uma percentagem de 37,9\% em 1991; em 1993, 54,3\% da população portuguesa, e ainda que se tenha registado uma ligeira quebra em 1996 e aquando da partida das tropas portuguesas para a Bósnia-Herzegovina, a opinião pública portuguesa parecia estar de acordo com a participação portuguesa nas operações de paz na ex-Jugoslávia. ${ }^{131}$

Quanto ao futuro da região em análise, sou bastante cética. É previsível que novos conflitos surjam, independentemente dos acordos de paz. De facto, verifica-se, sobretudo in loco, uma tensão a vários níveis. O desporto (em

${ }^{129}$ Nuno Severiano Teixeira, "Das campanhas de guerra às operações de paz: as intervenções militares portuguesas em teatro europeu" . Estratégia. Portugal na Bósnia - do isolamento ao envolvimento europeu. Instituto de Estudos Estratégicos e Internacionais. N. ${ }^{\circ} 14$. ( $^{\circ} .^{\circ}$ semestre) 1999. in <http://www.ieei.pt/publicacoes/artigo.php?artigo=266>. (Consultado a 23/09/2011).

${ }^{130}$ Eduardo Mascarenhas, "Brigada agasalha-se", in Diário de Notícias, 28/11/1995, Lisboa

${ }^{131}$ Nuno Severiano Teixeira, "Das campanhas de guerra às operações de paz: as intervenções militares portuguesas em teatro europeu” . Estratégia. Portugal na Bósnia - do isolamento ao envolvimento europeu. Instituto de Estudos Estratégicos e Internacionais. N. ${ }^{\circ} 14$. ( $^{\circ}{ }^{\circ}$ semestre) 1999. in <http://www.ieei.pt/publicacoes/artigo.php?artigo=266>. (Consultado a 23/09/2011). 
particular o futebol $)^{132}$ poderá ser um exemplo porventura inadequado mas elucidativo. A título de exemplo, a equipa que na época 1990/1991 havia conseguido a 36. ${ }^{\text {a }}$ Taça dos Campeões Europeus, o Estrela Vermelha de Belgrado (FK Crvena Zvezda) ${ }^{133}$, era constituída por jogadores oriundos de todas as repúblicas da federação jugoslava. Com o eclodir da guerra, a etnicidade foi desaparecendo, tendo originado e mantendo-se atualmente um plantel maioritariamente sérvio.

É uma zona onde se registam presentemente problemas sociais, económicos e políticos, que advêm das vicissitudes justamente de uma história com altos e baixos e sucessivos conflitos. Os Balcãs parecem deter um espírito demasiado temperamental e tempestuoso, estando na origem de conflitos que arrastaram a Europa para as malhas da guerra em várias ocasiões.

A Primeira Guerra Mundial teve início em Sarajevo, palco do assassinato do arquiduque Francisco Fernando a 28 de Junho de 1914, herdeiro do trono do Império Austro-Húngaro, ação planeada e executada pelo sérvio Gavrilo Princip, membro pertencente do grupo nacionalista que lutava em prol da unificação de todos os territórios, outrora grande parte deles integrados no Império Austro-Húngaro. A Segunda Guerra Mundial constitui um exemplo igualmente marcante. Foi local das mais horrendas atrocidades e massacres, opondo croatas ustase a sérvios, ciganos, judeus e croatas anti-ustase resultando, assim, na matança realizada por parte tanto de dirigentes, como militares de croatas que se haviam aliado às forças de Hitler e à sua ideologia.

Em tempos de crise ou falta de liderança, a paz torna-se débil e por consequência também a união entre os povos. Assim, a federação ex-jugoslava foi, essencialmente, um sistema, cujo funcionamento obteve resultados positivos tanto a nível económico, como a nível político-ideológico, registando porém uma quebra irreversível aquando da morte de Tito e pouco depois associada a uma recessão económica, criando, consequentemente, um fosso demasiado fundo nesta região.

Assim, os nacionalismos que se fizeram rapidamente sentir um pouco por toda a região a partir de 1980, dando especial destaque à capacidade de lide-

${ }^{132}$ Foi, a este título, elaborado um quadro explicativo na tentativa de demonstrar a emigração significativa de jogadores de futebol de origem jugoslava para Portugal, coincidente com o período das guerras na ex-Jugoslávia. Para mais informações, por favor consultar o Anexo E: Jogadores de futebol de origem jugoslava a atuar na Primeira Divisão portuguesa.

${ }^{133}$ Para mais informações ver European Cup History. Season 1990-91. Consultado a 21 de Julho de 2011. in <http://www.europeancuphistory.com/euro91 html>. Ver também informações sobre a emigração de jogadores jugoslavos para Portugal no Anexo E: Jogadores de futebol de origem jugoslava a atuar na Primeira Divisão portuguesa. 
rança e manipulação de Slobodan Milošević que, juntamente com a dissolução da Liga dos Comunistas, contribuíram para o fim de uma união que havia perdurado durante o modelo titista. As repúblicas, outrora jugoslavas, foram tomando, deliberadamente ou não, dependendo da perspetiva, caminhos diferentes. $\mathrm{O}$ desmantelamento de uma federação, que havia sido inicialmente pensada e criada com o objetivo de promover a convivência e a ligação de estados etnicamente díspares, tornando-os, assim, fortes a nível europeu e um modelo praticamente único no mundo, acarretou, efetivamente, pesadas consequências. Assim, a responsabilidade quanto ao desmembramento da antiga Jugoslávia deve-se, na minha opinião, às ambições, um tanto "desmesuradas" dos líderes políticos locais.

Em suma, esta investigação parece demonstrar que o conflito na Bósnia-Herzegovina ocupou efetivamente a agenda parlamentar, graças à Presidência Portuguesa das Comunidades Europeias (1992), e as primeiras páginas da imprensa partidária dos partidos políticos em análise, procurando revelar as posições das diferentes forças políticas.

Ainda assim, tanto o conflito na Bósnia-Herzegovina, como a vivência presentemente nos Balcãs, apesar dos esforços diplomáticos e debates, poderão resumir-se à seguinte ideia: "Perdoar sim, mas esquecer não!"134

${ }^{134}$ Diálogo extraído da produção cinematográfica de Kusturica, Emir. (1995). Underground, Barrandov Studios et al. Alemanha, França, República Federal da Jugoslávia, mais precisamente, aos [02:28:00]. 